\title{
Integrated geochronology of Acheulian sites from the southern Latium (central Italy): Insights on human-environment interaction and the technological innovations during the MIS 11-MIS 10 period
}

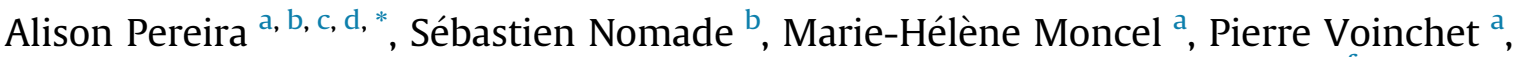 \\ Jean-Jacques Bahain ${ }^{a}$, Italo Biddittu ${ }^{e}$, Christophe Falguères ${ }^{a}$, Biagio Giaccio ${ }^{\mathrm{f}}$, \\ Giorgio Manzi ${ }^{\mathrm{g}}$, Fabio Parenti ${ }^{\mathrm{h}}$, Giancarlo Scardia ${ }^{\mathrm{i}}$, Vincent Scao ${ }^{\mathrm{b}}$, Gianluca Sottili ${ }^{\mathrm{j}}$, \\ Amina Vietti ${ }^{\text {a, }} \mathrm{k}$ \\ a Département Hommes et Environnements, Muséum National d'Histoire Naturelle, UMR 7194 du CNRS, 1 rue René Panhard, 75013 Paris, France \\ ${ }^{\mathrm{b}}$ Laboratoire des Sciences du Climat et de l'Environnement, LSCE/IPSL, CEA-CNRS-UVSQ Université Paris-Saclay, F-91191 Gif-sur-Yvette, France \\ ' Sezione di Scienze Preistoriche e Antropologiche, Dipartimento di Studi Umanistici, Università degli Studi di Ferrara, C.so Ercole d'Este I, 32, Ferrara, Italy \\ ${ }^{\mathrm{d}}$ Ecole française de Rome, Piazza Farnese, IT-00186, Roma, Italy \\ e Istituto italiano di Paleontologia Umana, Piazza Ruggero Bonghi, 2, Anagni (FR), Italy \\ ${ }^{\mathrm{f}}$ Istituto di Geologia Ambientale e Geoingegneria, CNR, Roma, Italy \\ ${ }^{g}$ Sapienza Universita di Roma, Dipartimento di Biologia Ambientale, Piazzale Aldo Moro 5, 00185 Roma, Italy \\ h Universidade Federal do Paraná, Curitiba, Brazil \\ i Universidade Estadual Paulista (UNESP), Instituto de Geociências e Ciências Exatas, Rio Claro, SP 13506-900, Brazil \\ j Sapienza Università di Roma, Dipartimento di Scienze della Terra, Piazzale Aldo Moro 5, 00185 Roma, Italy \\ k Dipartimento di chimica, Università degli Studi di Torino, 10125 Turin, Italy
}

\section{A R T I C L E I N F O}

\section{Article history:}

Received 20 September 2017

Received in revised form

26 February 2018

Accepted 14 March 2018

Available online 30 March 2018

\section{Keywords:}

${ }^{40} \mathrm{Ar} /{ }^{39} \mathrm{Ar}$

ESR on bleached quartz

ESR/U-series

Technical analysis

Latium

\begin{abstract}
A B S T R A C T
We have explored the multimethod approach combining ${ }^{40} \mathrm{Ar} /{ }^{39} \mathrm{Ar}$ on single crystal, ESR on bleached quartz, and ESR/U-series on teeth to improve the age of four neighbours "Acheulian" sites of the Frosinone Province (Latium, Italy): Fontana Ranuccio, Cava Pompi (Pofi), Isoletta, and Lademagne. Ages obtained by the three methods are in mutual agreement and confirm the potential of dating with confidence Middle Pleistocene sites of Italy using these methods.

At Fontana Ranuccio, the ${ }^{40} \mathrm{Ar} /{ }^{39} \mathrm{Ar}$ age $(408 \pm 10 \mathrm{ka}$, full external error at $2 \sigma)$ obtained for the archaeological level (unit FR4) and geochemical analyses of glass shards performed on the Unit FR2a layer allow us to attribute the studied volcanic material to the Pozzolane Nere volcanic series, a wellknown caldera-forming event originated from the Colli Albani volcanic district. These new data ascribe the Fontana Ranuccio site, as well as the eponym faunal unit, to the climatic optimum of Marine Isotope Stage (MIS) 11. Ages obtained for the Cava Pompi, Isoletta, and Lademagne sites cover a relatively short period of time between $408 \mathrm{ka}$ and $375 \mathrm{ka}$, spanning MIS 11 climatic optimum to the MIS 11-10 transition. Analysis of small collections of lithic industries, bifacial tools, and small cores technologies from Isoletta, Lademagne, and the neighbour site of Ceprano-Campogrande shows common technical strategies for the period comprised between MIS 11 and MIS 9 (410-325 ka), such as the elaboration of flaked elephant bone industries found over the whole Latium region. However, some features found only in the Frosinone province area, like large-sized bifaces, suggest particular regional behaviours. The presence of one Levallois core in the oldest layer of Lademagne (i.e. $>405 \pm 9 \mathrm{ka}$ ) suggests a punctual practice of this technology, also proposed as early as MIS 10/11 in the neighbour site of Guado San Nicola (Molise) in central Italy.
\end{abstract}

() 2018 Elsevier Ltd. All rights reserved.

\footnotetext{
* Corresponding author. Département Hommes et environnements, Muséum national d'Histoire naturelle, UMR 7194 du CNRS, 1 rue René Panhard, 75013 Paris, France.

E-mail address: alison.pereira@mnhn.fr (A. Pereira).
} 


\section{Introduction}

The time interval between 450 and $300 \mathrm{ka}$ is from an archaeological viewpoint a period of emergence of several cultural and technological innovations in hominin evolution and regionalisation of cultural features (Moncel et al., 2017). This time span encompasses the Marine Isotopic Stages (MIS) 11 and 9; the former of these sea-level high-stands is a low eccentricity interglacial that represents the culmination of a series of modifications of the Earth's climate system, known as the Early Middle Pleistocene Transition (EMPT, Head and Gibbard, 2015). Started at around 1.4 Ma, the EMPT transition is characterised by a progressive shift of the climatic cycles from $\sim 41 \mathrm{ka}$ to $\sim 100 \mathrm{ka}$, and increase of the amplitude and asymmetry of the climatic oscillations, which induced longer, more intense and dryer condition during glacial periods (Berger et al., 2005; Head et al., 2008). Recent studies suggest influence of palaeoenvironnemental and climatic conditions on possible migration and techno-cultural development of hominin populations that lived in Western Europe during MIS 12 to MIS 10 (Moncel et al., 2017). After the very cold and dry MIS 12 and particularly during the MIS 11, when 100 ka cycles definitively established, several lower Palaeolithic sites suggest the expansion and regionalisation of the "Acheulian" culture (technological Mode 2 with bifacial technology) over the entire Western European continent. Generalization and high standardization of various types of bifacial tools also occurred during this period linked to a sporadic domestication of the fire (Kretzoi and Dobosi, 1990) and in some punctual cases with the emergence of new behaviours, such as the Levallois core technology (Mode 3) (Adler et al., 2014; Peretto et al., 2016; Pereira et al., 2016). However, time and evolutionary modes of the pre-Neanderthalian lineage during the second part of the Middle Pleistocene remain heavily debated as current researches are hampered by the relatively lack of long and well-preserved archaeological sequences and of precise and accurate chronologies. In particular, the acquisition of a reliable chronology is limited by the low precision of most of the dating methods suitable for the 400-800 ka timespan (e.g., palaeodosimetric methods such as Electron Spin resonance (ESR) and thermoluminescence (TL)), which is beyond the limit of more precise dating methods such as $\mathrm{U} / \mathrm{Th}$. Therefore, acquiring a fine and robust chronological framework for the European Lower Palaeolithic is definitively a challenging task. Such a difficulty makes the reconstruction of the evolutionary techno-cultural processes largely uncertain, as they often rely only on speculative correlations that are not fully validated by independent chronological data.

On this background, the Mediterranean basin and particularly the Italian territory are of particular interest in Western-European Lower Palaeolithic panorama. Three main peculiar features make this area unique in Western Europe for investigating the Lower Palaeolithic times: 1) There is a large number of well-preserved archaeological sites tentatively ascribable to the MIS 11-9 interval (Moncel et al., 2016), which in turn depends on two favourable factors. The first one is the Quaternary geodynamic context of the Italian Peninsula, which favoured the development of intermountain tectonic basins filled with fluvial and lacustrine sediments (Vezzani et al., 2010) that are ideal geological settings for the preservation of the Palaeolithic occupations (e.g., Biddittu et al., 1979; Muttoni et al., 2009; Villa et al., 2016; Nicoud et al., 2016). The second one relies on the fact that the Mediterranean basin and the Italian Peninsula played a role of refuge for temperate vegetation during glacial periods despite the general opening of landscapes (Hofreiter and Stewart, 2009; Orain et al., 2013). The persistence of temperate taxa and fertile volcanic soils may have contributed to the large mammal herds and hominids settlements through this area (Moncel et al., 2017).
2) Besides being fundamental for preserving the archaeological traces, Italian sedimentary basins are also exceptional archives of both local and regional environmental and climatic changes (e.g., Russo Ermolli and Cheddadi, 1997; Vezzani et al., 2010; Petrosino et al., 2014; Regattieri et al., 2016; Degeai et al., 2018). They can provide crucial information for framing the evolution of lithic technology and understanding its potential interplay with the various components of the human ecosystems.

3) Last, but not least, the continuous K-rich explosive volcanism from Italian magmatic provinces led to the deposition of numerous tephra and abundant volcanic material all over Central and Southern Italy, allowing the use of the ${ }^{40} \mathrm{Ar} /{ }^{39} \mathrm{Ar}$ dating method to provide precise and accurate chronological control for both palaeoenvironmental records (e.g., Karner and Marra, 1998; Giaccio et al., 2015; Petrosino et al., 2014; Marra et al., 2014, 2016; Regattieri et al., 2016) and archaeological sites (e.g., Peretto et al., 2016; Pereira et al., 2015, 2016; Villa et al., 2016; Degeai et al., 2018). The ${ }^{40} \mathrm{Ar} /{ }^{39} \mathrm{Ar}$ method offers also the opportunity of integrating and eventually testing the ages provided by palaeodosimetric methods (e.g., ESR on bleached quartz and ESR/U-series on teeth; Pereira et al., 2015, 2016), commonly applied to date Middle Pleistocene sites in Northern Europe, where the ${ }^{40} \mathrm{Ar} /{ }^{39} \mathrm{Ar}$ can only rarely be used (e.g., Bahain et al., 2007; Voinchet et al., 2010; Moncel et al., 2013).

The present study is focused on the Latina valley where numerous Lower Palaeolithic sites have been discovered over the last 40 years (Fig. 1). Main goal is to build a homogeneous chronological framework for 4 adjacent Acheulian sites (Fig. 1): Fontana Ranuccio, Isoletta, Lademagne, and Cava Pompi (Pofi) (Biddittu et al., 1979, 2012; Biddittu and Segre, 1984). This chronological framework is defined using several methods based on different physical processes (radioisotopy and palaeodosimetry) to ensure the most accurate chronology following the approach developed in Pereira et al. (2015, 2016).

Applied dating methods in our work are $(i){ }^{40} \mathrm{Ar} /{ }^{39} \mathrm{Ar}$ on single crystal of K-feldspars, (ii) ESR on bleached quartz grains and (iii) ESR/U-series on large mammal teeth. At Fontana Ranuccio we also applied (iv) the tephrochronology approach, an indirect dating method based on chemical fingerprinting of volcanic deposit (level FR2a, Fig. 2). This last method allows in the most favourable case to identify a specific eruption and therefore the age of the volcanic material. All studied sites are found within alluvial deposits that contain material potentially suitable for each of the considered dating methods; i.e., ( $i$ and $i v$ ) tephras or reworked volcanoclastic material originated from the Middle Pleistocene volcanoes located close to the investigated sites (i.e., Colli Albani, Ernici-Valle Latina and Roccamonfina districts; Fig. 1, (Karner et al., 2001; Gaeta et al., 2016); Basilone and Civetta, 1975; Civetta et al., 1981, Boari et al., 2009; Rouchon et al., 2008) - (ii) quartz and (iii) mammal teeth.

The new chronological framework will be used to compare for the first time with confidence at local scale, a corpus of bifacial tools from Isoletta, Lademagne (Biddittu and Segre, 1984; Biddittu et al., 2012; Comerci et al., 2015 dated in this study) and Campogrande sites (e.g., Manzi, 2016). The studied industries are then compared with the bibliographic data available for Fontana Ranuccio (Biddittu and Segre, 1984). Finally, in order to identify possible regional/ micro-regional affinities or differences, the comparison is extended to other sites sharing a similar age on a wider regional scale, including Latium (Torre in Pietra, Castel di Guido; Villa et al., 2016) and Molise (Guado San Nicola; Pereira et al., 2016).

\section{Geological settings}

The Latina Valley is delimited by two major tectonic structures of regional relevance: the Olevano-Antrodoco line to the West and 


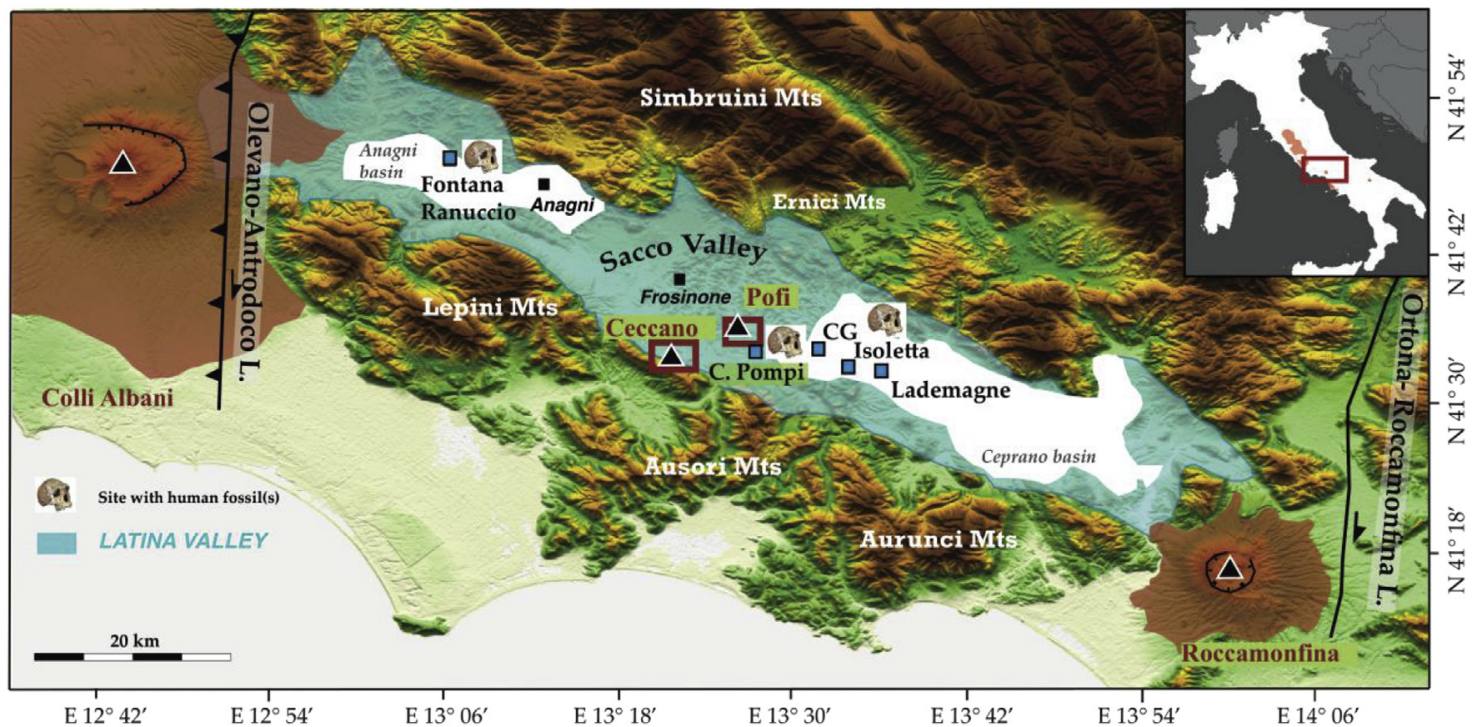

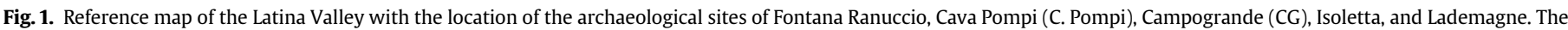
main volcanic centres are also shown (black triangles).

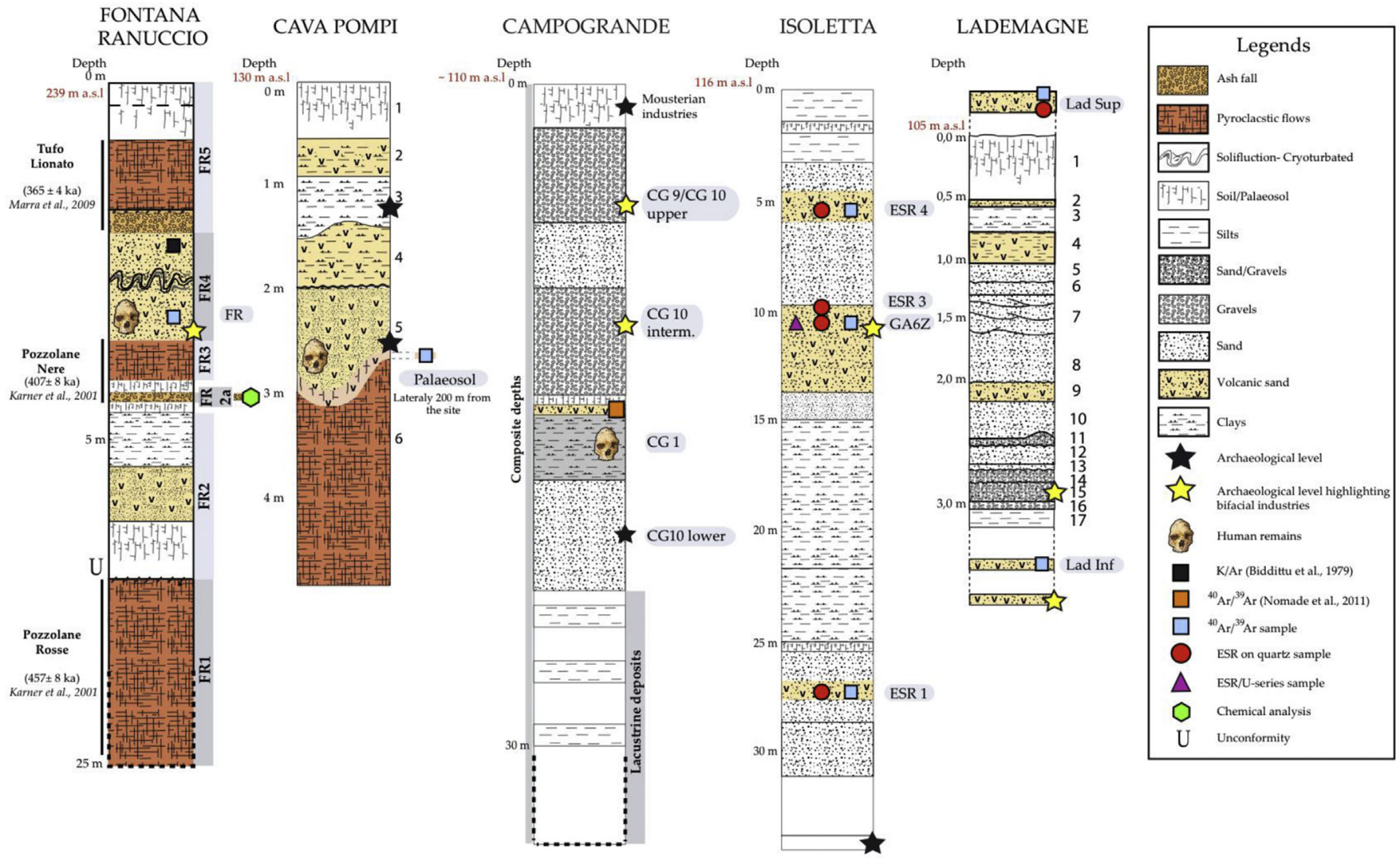

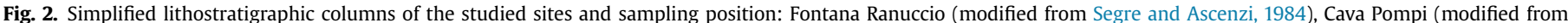

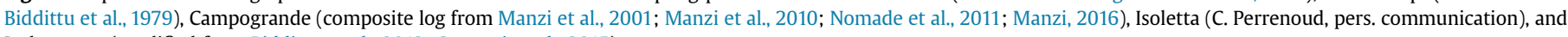
Lademagne (modified from Biddittu et al., 2012, Comerci et al., 2015).

the Ortona-Roccamonfina line to the South (Fig. 1; Locardi, 1988; Sani et al., 2004). This valley is a tectonic depression located on the Tyrrhenian side of the Apennines fold and thrust belt, embedded between the Central Apennines at E and the Lepini and Ausoni ranges at W (Sani et al., 2004, Fig. 1). This area was subjected to
$\mathrm{NE}-\mathrm{SW}$-oriented extensional tectonic that led to the formation of tectonic basins (Anagni and Ceprano) since late Pliocene (Carrara et al., 1995; Segre and Ascenzi, 1984, Fig. 1). In Frosinone province, the Latina valley is bounded to the northwest by the Colli Albani volcanic district that was active between $608 \mathrm{ka}$ and $36 \mathrm{ka}$ 
(Gaeta et al., 2016, and references therein) and to the southeast by the Roccamonfina volcanic complex, characterised by an intense eruptive activity between 550 and 90 ka (Giannetti, 2001; Rouchon et al., 2008). Within the Latina Valley, the Ernici-Valle Latina volcanic district consists of about 20 monogenetic volcanic centres characterised by weak to moderate explosive activity between 700 and 100 ka (Civetta et al., 1979; Boari et al., 2009, Fig. 1).

\section{Stratigraphic and archaeological background}

\subsection{Fontana Ranuccio}

The archaeological site of Fontana Ranuccio, located $60 \mathrm{~km}$ southeast of Rome in the Anagni basin (Fig. 1), was discovered in 1976 within a succession of pyroclastic deposits. Lithic industries, bone tools, as well as four hominin teeth were found embedded within volcanoclastic sediments (level FR4 in Fig. 2, characteristic of a volcanic lahar deposit, see details below) previously dated by ${ }^{40} \mathrm{~K} /{ }^{40} \mathrm{Ar}$ to $458 \pm 12 \mathrm{ka}$ ( $2 \sigma$ analytical uncertainty, see Biddittu et al., 1979). The hominin fossils are currently interpreted as belonging to Homo heidelbergensis (Rubini et al., 2014). Faunal assemblage found in level FR4 (Fig. 2) is ascribed to the last faunal unit of the Galerian Mammal Age (GMA hereafter; Gliozzi et al., 1997; Sardella et al., 2006) and compatible with a MIS 13 or MIS 11 age (Ascenzi et al., 1993; Marra et al., 2014). At the base of unit FR4 is found a primary pyroclastic tephra layer (pyroclastic flow FR3) characterised at the base by an ash fall (FR2a, Fig. 2). At the top of the stratigraphy is a reddish lithoid tuff (Fig. 2). This upper volcanic deposit is interpreted in the literature as the Tufo Lionato (Biddittu et al., 1979), a well-known volcanic unit of the Colli Albani (Villa Senni lower pyroclastic-flow unit; Freda et al., 1997), dated to $365 \pm 4$ ka (Marra et al., 2009, Fig. 2).

The locations (geographic coordinates) of the archaeological sites studied in this work can be found in the text and in supplementary dataset Fig. S1.

\subsection{Isoletta, Lademagne, and Campogrande}

The Isoletta, Lademagne, and Campogrande localities form a cluster of lithostratigraphically relatively homogenous sites located in the Ceprano tectonic basin, around $30 \mathrm{~km}$ SE from the Anagni basin (Fig. 1).

The Isoletta site is located few kilometres SE from the town of Ceprano (156 m a.s.l, $41^{\circ} 31^{\prime} 44.86^{\prime \prime} \mathrm{N}, 13^{\circ} 34^{\prime} 0.16^{\prime \prime}$ E, see Fig. S1) at the confluence of Liri and Sacco Rivers (Fig. 1). The stratigraphic sequence (more than $30 \mathrm{~m}$-thick) mainly consists of sand and gravel sustaining a fluvial terrace (Fig. 2). It was discovered in the 1970s but was studied in details during high-speed train railways construction (1998-1999). It is very rich in reworked volcanic material, as well as tephra layers (Fig. 2). On this site two archaeological levels were identified. The lowermost one is characterised by mode 1 lithic and bones industries (Fig. 2, Biddittu, 2004), whereas the uppermost one (GA6Z, Fig. 2) displayed Mode 2 artefacts and GMA fauna (Biddittu, 1974, 2004).

Discovered in 1965, the Lademagne site is an archaeological section located only few kilometres from the San Giovanni Incarico Lake, $5 \mathrm{~km}$ westwards of Isoletta, within the ancient Lirino paleolake (105 $\mathrm{m}$ a.s.l, 41 ${ }^{\circ} 31^{\prime} 16.68^{\prime \prime} \mathrm{N}, 1^{\circ} 35^{\prime} 0.72^{\prime \prime} \mathrm{E}$, Fig. S1). Lithologically, Lademagne is very similar to the nearby Isoletta (Fig. 2) and is mainly composed of sand and gravel deposits with inter-bedded volcanic-rich sediments (Comerci et al., 2015). Two archaeological layers with Mode 2 lithic pieces are mentioned in the literature (Biddittu et al., 2012). The deepest one was found $87 \mathrm{~m}$ a.s.l and the highest one $102 \mathrm{~m}$ a.s.l. (Fig. 2). They both present similar palaeontological and archaeological assemblages with bifacial and bone tools (Biddittu et al., 2012). Also the palaeontological assemblage recovered at both levels pertain to the GMA (Biddittu et al., 2012).

The Campogrande locality includes a corpus of relatively stratigraphically similar archaeological sites found within a small area $\left(1 \mathrm{~km}^{2}, 41^{\circ} 31^{\prime} 43.35^{\prime \prime} \mathrm{N}, 13^{\circ} 28^{\prime} 45.92^{\prime \prime} \mathrm{E}\right.$, see Fig. S1 and Fig. 2). Three different sites were identified at Campogrande: CG 1 (the site of the Ceprano calvarium), CG 9, and CG 10. The calvarium, now attributed to $H$. heidelbergensis (Di Vincenzo et al., 2017), was discovered within a clay layer in CG1 (Fig. 2) stratigraphically below the Acheulian levels in the same area, namely CG 9 and CG 10 (Ascenzi et al., 1996, 2000; Manzi et al., 2001; Manzi, 2016). The age of the Ceprano calvarium was firstly estimated around 900-800 ka based on stratigraphic inferences, on its "archaic" morphological characteristics (Ascenzi et al., 1996, 2000), and on the possible association with Mode 1 lithic tools. Then, palaeomagnetic analyses on a core drilled at the CG1 site (Muttoni et al., 2009) and ${ }^{40} \mathrm{Ar} /{ }^{39} \mathrm{Ar}$ single crystal measurements from a volcanic sand (K-layer) $30 \mathrm{~cm}$ above the calvarium layer (Nomade et al., 2011) constrained the Ceprano hominin to the MIS 11-MIS 10 interval. The obtained age for the youngest eruption recorded in the K-layer was $353 \pm 8 \mathrm{ka}$ ( $2 \sigma$ analytical error), giving a minimum age for this layer and also for the calvarium. A MIS 11 age (430-385 ka) was also suggested for the layer where the human specimen was found, based on stratigraphic, palynological, geochemical, taphonomical, micromorphological, and archaeological studies (Manzi et al., 2010). This fossil adds an amount of unexpected variabilities into the range of variations known for the Middle Pleistocene $H$. heidelbergensis populations in Europe (Manzi, 2016). Thanks to the age obtained for the K-layer, also the Mode 2 industries found in sections CG9 and CG10 localities have been dated to a maximum age of $353 \pm 8 \mathrm{ka}$.

\subsection{Cava Pompi}

The Cava Pompi site is located near the city of Pofi (Fig. 1; Biddittu and Segre, 1978). The site was discovered in 1961 in a quarry and covers an area of $40 \mathrm{~m}^{2}\left(41^{\circ} 33^{\prime} 31.24^{\prime \prime} \mathrm{N}, 13^{\circ} 26^{\prime} 18.58^{\prime \prime} \mathrm{E}\right)$. Two different archaeological levels were identified (level 5 and level 3 in Fig. 2). In level 5 were discovered rare lithic industries on flake and several hominin remains (Fig. 2): one ulna, one tibia and a part of skull attributed to $H$. heidelbergensis (Biddittu and Segre, 1977). Few artefacts in bones and lava were also recovered (Biddittu and Segre, 1978). Fauna from level 5 is mainly typical of GMA unit, including elephants, cervids, megaceros, and primates (macacos). In level 3, rare artefacts and equids bones are mentioned.

\section{Material and methods}

The dating methods used in our study are the ${ }^{40} \mathrm{Ar} /{ }^{39} \mathrm{Ar}$ on single grains, the ESR (Electron Spin Resonance) on bleached quartz and, for Isoletta site, the ESR/U-series techniques. The ${ }^{40} \mathrm{Ar} /{ }^{39} \mathrm{Ar}$ method is a radio-isotopic technique and the ESR techniques are palaeodosimetric methods. The ${ }^{40} \mathrm{Ar} /{ }^{39} \mathrm{Ar}$ is a very accurate and precise method (uncertainties close to $1 \%$ ), but it can only be used on volcanic minerals. At contrary, the ESR techniques are ubiquitous but less precise in relation to the great number of parameters $(>20)$ involved in the age calculation (leading generally to an uncertainty of $8-15 \%)$. The ESR on bleached quartz allows to date fluvial deposits, whereas the ESR/U-series is commonly used to obtain a chronological constrain from large mammal's teeth recovered in the archaeological sequences. 


\subsection{Field investigations and sampling}

\subsubsection{Fontana Ranuccio}

New field investigations were performed in order to obtain an accurate stratigraphic framework and chronological constraints for Fontana Ranuccio. The sample previously dated by ${ }^{40} \mathrm{~K} /{ }^{40} \mathrm{Ar}$ $(458 \pm 12 \mathrm{ka}$; Biddittu et al., 1979) was collected during the first excavation campaign at the bottom of the archaeological layer (Fig. 2). The sample dated in this study by ${ }^{40} \mathrm{Ar} /{ }^{39} \mathrm{Ar}$ on single leucite crystals was sampled in 2008 by A.G. Segre at the top of the stratigraphic level FR4, about $1 \mathrm{~m}$ above the previous dated sample (Fig. 2). Geochemical analyses (section 5.1) were performed on volcanic glasses extracted from the stratigraphic Unit FR2a, which is a primary pyroclastic ash fall (bottom of level 10 of Segre Naldini et al., 2009). The age obtained in our study is presented section 5.2.

\subsubsection{Isoletta, Lademagne and Campogrande}

4.1.2.1. Isoletta. Three levels were sampled in 1998 during a rescue fieldwork mission for both ${ }^{40} \mathrm{Ar} /{ }^{39} \mathrm{Ar}$ and ESR on bleached quartz dating methods (see Fig. 2). One sample was collected from the level GA6Z, corresponding to the "Acheulian" layer (Fig. 2), the ESR 4 sample was taken $5 \mathrm{~m}$ stratigraphically above GA6Z (Fig. 2), and the ESR 1 sample at $27 \mathrm{~m}$ depth. A fourth sample ESR 3 it could only be used only for ESR analysis on bleached quartz due to the lack of volcanic material. In the same fieldwork, one cervid tooth (ISOL1401) was extracted from a mandible recovered from the GA6Z archaeological level for ESR/U-series dating.

4.1.2.2. Lademagne. Two samples were taken for ${ }^{40} \mathrm{Ar} /{ }^{39} \mathrm{Ar}$ dating on single crystal (stratigraphic position shown in Fig. 2), the first one at the top of the stratigraphy (Lad Sup) and the second one framed between the two archaeological layers (Lad Inf, Fig. 2). Lad Sup was also sampled for ESR on quartz dating (Fig. 2).

4.1.2.3. Campogrande. Because of the recent chronological constraints provided by Nomade et al. (2011) we did not pursue once again this site from a geochronological point of view, but we however analysed the lithic assemblages from CG 9 and CG 10 in the framework of our study.

\subsubsection{Cava Pompi}

The former archaeological section of Cava Pompi is not accessible anymore. To obtain a chronological indication we recognized and sampled for ${ }^{40} \mathrm{Ar} /{ }^{39} \mathrm{Ar}$ dating the palaeosol at the base of the main archaeological layer (level 5, Fig. 2) in a section outcropping at about $200 \mathrm{~m}$ southeast from the original site, corresponding to the sole exposed area of the original quarry walls that is still not covered by vegetation.

\subsubsection{Summary of the selected samples}

The geological context of the studied sites has been described above, but for sake of clarity the samples that we analysed and dated are resumed below:

- At Fontana Ranuccio, the Unit FR4, corresponding to a volcanic lahar, remobilising the pyroclastic flow just below (level FR3, Fig. 2), rich in bones and archaeological artefacts and characterised by hominin remains, was dated by ${ }^{40} \mathrm{Ar} /{ }^{39} \mathrm{Ar}$. On Unit FR2a (pyroclastic ash fall) geochemical analyses were done (see Fig. 2).

- At Cava Pompi, due to the scarcity of volcanic material suitable for ${ }^{40} \mathrm{Ar} /{ }^{39} \mathrm{Ar}$, only the reddish palaeosol found directly below the archaeological layer (volcanic sand) was analysed (see Fig. 2).
- At Isoletta, three levels were dated by ${ }^{40} \mathrm{Ar} /{ }^{39} \mathrm{Ar}$ (ESR 4, GA6Z, ESR 1, see Fig. 2), three by ESR on bleached quartz (ESR 4, ESR3, GA6Z and ESR 1, see Fig. 2) and one by ESR-U/Th (GA6Z). All the selected levels, included the archaeological level GA6Z, are volcanic sands rich in quartz.

- At Lademagne, two fluvial layers (sands) reworking volcanic minerals (Lad Inf and Sup) were selected for the ${ }^{40} \mathrm{Ar} /{ }^{39} \mathrm{Ar}$ dating approach. Lad Sup was also dated by ESR on bleached quartz.

\section{2. ${ }^{40} \mathrm{Ar} /{ }^{39} \mathrm{Ar}$ on single crystal protocol}

All the collected samples were crushed and sieved to different meshes, between $1 \mathrm{~mm}$ and $250 \mu \mathrm{m}$. Transparent and unaltered sanidine and/or leucite crystals, ranging between $500 \mu \mathrm{m}$ and $1 \mathrm{~mm}$, were handpicked under a binocular (at least 30 crystals for each sample). Selected crystals were then leached with a 5-7\% HF acid solution to remove the groundmass. After being washed in several distilled water baths crystals extracted from each layer were loaded in aluminium disks and irradiated in the $\beta 1$ tube of the Osiris reactor, CEA Saclay (France). After irradiations, samples were separately transferred in a copper sample holder and put into a double vacuum window. Crystals were individually fused using a $\mathrm{CO}_{2}$ laser $(25 \mathrm{~W}$, using $10 \%$ of the nominal power). Extracted gases were purified by two GP 110 getters ( $\mathrm{ZrAl}$ ) and argon isotopes measured using a micromass 5400 mass spectrometer equipped with an electron multiplier Balzers 217 SEV SEN coupled with an ion counter (full analytical protocol is detailed in Nomade et al., 2010). Neutron J fluence for each sample was calculating using co-irradiated Alder Creek Sanidine (ACs-2) standard with an age of 1.193 Ma (Nomade et al., 2005) (Fontana Ranuccio: $J=0.0002631 \pm 0.0000037$; Cava Pompi: $\mathrm{J}=0.00040070 \pm 0.0000028$; Isoletta: ESR 4, $\mathrm{J}=0,00033800 \pm 0.00000068, G A 6 Z, \mathrm{~J}=0,00035590 \pm 0.00000107$, ESR $1,2 \mathrm{~J}=0,00036664 \pm 0.00000073$, Lademagne: Lad Sup, $\mathrm{J}=0,00024860 \pm 0.00000124$, Lad Inf, $\mathrm{J}=0,00042210 \pm$ $0.00000211)$. Procedural blank measurements were performed after every three unknown samples. Mass discrimination correction was monitored by measurements of air argon of various beam sizes and was calculated relative to $\mathrm{a}^{40} \mathrm{Ar} /{ }^{36} \mathrm{Ar}$ ratio of 298.56 (Lee et al., 2006).

\subsection{Geochemical analysis at Fontana Ranuccio}

Major and minor oxide element compositions were determined on glassy scoria fragments collected in Unit FR2a (see stratigraphic details in section 5.1.). The analyses were carried out at the Istituto di Geologia Ambientale e Geoingegneria of the Italian National Research Council (IGAG-CNR) (Rome, Italy) using a Cameca SX50 electron microprobe equipped with a five-wavelength dispersive spectrometer. Operating conditions were set to $15 \mathrm{kV}$ accelerating voltage; $15 \mathrm{nA}$ beam current; $10-15 \mu \mathrm{m}$ beam diameter; $20 \mathrm{~s}$ per element counting time; wollastonite (for Si and $\mathrm{Ca}$ ), corundum (for $\mathrm{Al}$ ), diopside (for $\mathrm{Mg}$ ), andradite (for $\mathrm{Fe}$ ), rutile (for $\mathrm{Ti}$ ), orthoclase (for K), jadeite (for $\mathrm{Na}$ ), phlogopite (for $\mathrm{F}$ ), potassium chloride (for $\mathrm{Cl}$ ), barite (for $\mathrm{S}$ ), and metals (for $\mathrm{Mn}$ ) were used as standards. The Ti content was corrected for the overlap of Ti-K $\alpha$ peaks. In order to evaluate the accuracy of the electron microprobe analyses, three international secondary standards (Kakanui augite and rhyolite RLS132 glasses from the United States Geological Survey) were measured prior of the analytic run. For full details of the secondary standard analyses run alongside with the Fontana Ranuccio layer FR2a refer to the Supplementary Table S1.

\subsection{ESR on bleached quartz}

In this work, both ESR signals of the Aluminum (Al) and Titanium (Ti) centres were studied. 
The quartz grains extraction and preparation protocol of quartz is described in Voinchet et al. (2004).

Each sample was split after extraction in 11 aliquots. Nine of them were irradiated with a gamma ${ }^{60}$ Co source (CEA Saclay, France) emitting $1.25 \mathrm{MeV}$ radiation with a dose rate of around $200 \mathrm{~Gy} / \mathrm{h}$. The 9 additive doses are 264, 431, 653, 1048, 1663, 2640, $4460,8010,12500 \mathrm{~Gy}$. One aliquot was conserved as natural reference. In order to determine the unbleachable part of the ESR-Al signal one other aliquot was exposed to light in a Dr Honhle SOL2 solar simulator during $1600 \mathrm{~h}$ (light intensity between 3.2 and 3.4 $10^{5}$ Lux). Then, each set of 11 aliquots was measured at least three times by ESR at $107 \mathrm{~K}$ using Bruker EMX spectrometer and each aliquot was measured each time three times after an approximately $120^{\circ}$ rotation of the tube in the ESR cavity, in order to consider angular dependence of the signal due to sample heterogeneity.

For titanium centre the acquisition parameters used are: $10 \mathrm{~mW}$ microwave power, 1024 points resolution, $20 \mathrm{mT}$ sweep width, $100 \mathrm{kHz}$ modulation frequency, $0.1 \mathrm{mT}$ modulation amplitude, 40 ms conversion time, $20 \mathrm{~ms}$ time constant and 2 scans. The signal intensity is measured using the Ti-Li option D (Duval and Guilarte, 2015). For the aluminum ESR centre study, the acquisition parameters used are: $5 \mathrm{~mW}$ microwave power, 1024 points resolution, $20 \mathrm{mT}$ sweep width, $100 \mathrm{kHz}$ modulation frequency, $0.1 \mathrm{mT}$ modulation amplitude, $40 \mathrm{~ms}$ conversion time, $20 \mathrm{~ms}$ time constant and 1 scan. The signal intensity is measured between the top of the first peak at $\mathrm{g}=2.018$ and the bottom of the 16 th peak at $\mathrm{g}=2.002$ of the Aluminum hyperfine structure (Toyoda and Falguères, 2003). Equivalent doses $\left(D_{e}\right)$ were then determined from the obtained ESR intensities vs doses growth curve using an exponential + linear function (Duval et al., 2009; Voinchet et al., 2013) with Microcal OriginPro 8 software with $1 / \mathrm{I}^{2}$ weighting. For the age calculation, the dose rates $D_{a}$ were calculated from the radionuclides contents of the sediments and taking into account the in situ gamma-rays data and the location of the samples in the stratigraphic succession.

Dose rate $\left(D_{a}\right)$, provided by sediments surrounding the sample, is obtained from the sum of the alpha, beta, gamma and cosmic-ray contributions. Gamma dose rate is determined by in situ measurements using an Inspector 1000 multichannel gamma spectrometer (Canberra). This gamma dose is estimated using the threshold approach (Mercier and Falguères, 2007). External alpha and beta contributions are calculated from the sediment radioelement contents ( $\mathrm{U}, \mathrm{Th}$, and $\mathrm{K}$ ) determined in laboratory by high resolution and low back ground gamma-spectrometry (Yokoyama and Nguyen, 1980). Age calculations are performed using the dose-rate conversions factors from Adamiec and Aitken (1998), a kvalue of 0,15 $\pm 0,1$ (Yokoyama et al., 1985; Laurent et al., 1998), alpha and beta attenuations from Brennan (2003) and Brennan et al. (1991), water attenuation from Grün (1994), and a cosmic dose rate calculated from the equations of Prescott and Hutton (1994a,b). The internal dose rate was considered as negligible because of the low contents of radionuclides usually found in quartz grains (Murray and Roberts, 1997; Vandenbergue et al., 2008). ESR age estimates are given with one sigma error range.

\subsection{ESR/U-series}

Combined ESR/U-series dating was applied on a lower second molar $\left(\mathrm{M}_{2}\right)$ of a mandible of Cervidae collected from the Acheulian layer (GA6Z) (see Fig. 3).

The sample was prepared according to the protocol described in Bahain et al. (2010). The different dental tissues were mechanically separated. The outer surface of the enamel layer was precisely cleaned with a dental drill and a part of its surface was removed in order to eliminate the contribution of external alpha-radiations and potential contaminations from dentine and sediments. The enamel

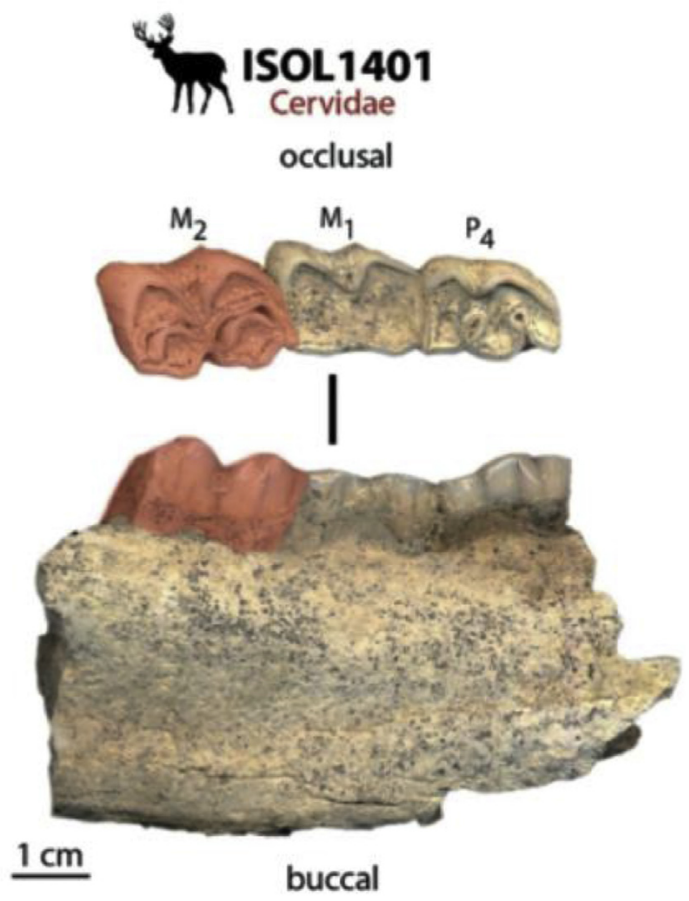

Fig. 3. Cervidae mandible collected at Isoletta for combined ESR/U-series dating. In red, the lower second molar $\mathrm{M}_{2}$ (ISOL1401), chosen for the analysis (Vietti, 2016). (For interpretation of the references to colour in this figure legend, the reader is referred to the Web version of this article.)

was grounded and sieved. The obtained $0-200 \mu \mathrm{m}$ powder was then split in 10 aliquots, whose 9 were irradiated with increasing gamma-doses using ${ }^{60}$ Co gamma-source (Saclay) from doses ranging from 264 to $12500 \mathrm{~Gy}$ (all the doses are indicated in Table S2).

ESR measurements were performed on EMX Bruker ESR spectrometer using the following parameters: $10 \mathrm{~mW}$ microwave power, $0.1 \mathrm{mT}$ modulation amplitude, $10 \mathrm{mT}$ scan range, room temperature and $100 \mathrm{kHz}$ frequency modulation. Four measurements were performed for each aliquot in different days. A doseresponse curve (ESR intensities vs doses) was then built and the equivalent dose $\left(D_{E}\right)$ was determined from the experimental data set (Table S2) using a single exponential function following the

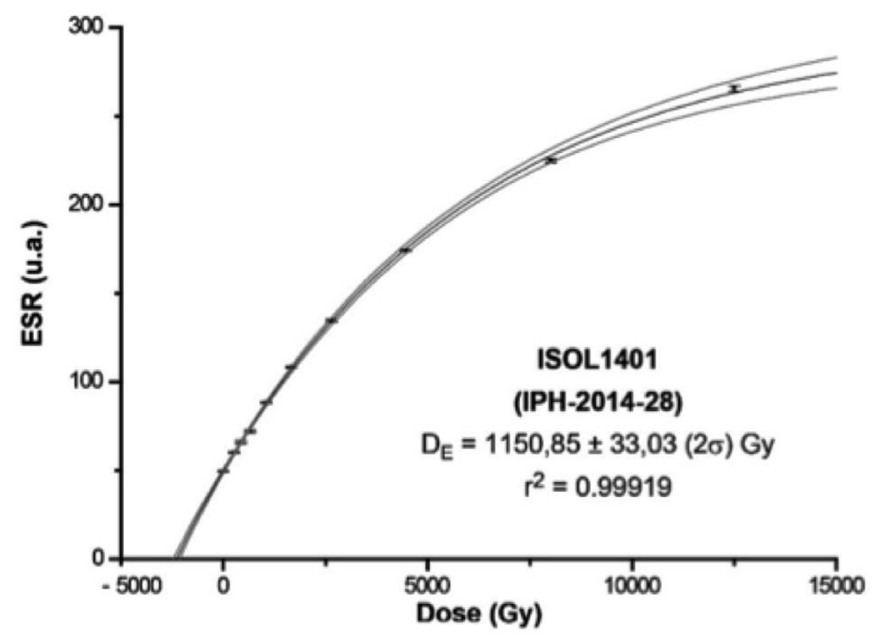

Fig. 4. Equivalent dose determination of ISOL1401 using Microcal OriginPro 8 software (Vietti, 2016). 
Table 1

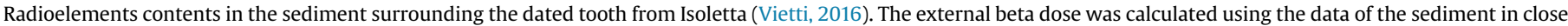
association with the tooth, while the gamma dose was calculated taking into account the sediments located in the vicinity.

\begin{tabular}{|c|c|c|c|}
\hline Sediment samples & ${ }^{238} \mathrm{U}(\mathrm{ppm})$ & ${ }^{232} \mathrm{Th}(\mathrm{ppm})$ & ${ }^{4} \mathrm{~K}(\%)$ \\
\hline Sands above the Acheulian level & $1.40 \pm 0.06$ & $1.07 \pm 0.07$ & $0.23 \pm 0.01$ \\
\hline Acheulian level (in association with the mandible) & $5.18 \pm 0.22$ & $23.08 \pm 0.38$ & $0.95 \pm 0.02$ \\
\hline Acheulian level (far from the mandible) & $1.62 \pm 0.14$ & $9.37 \pm 0.23$ & $2.39 \pm 0.03$ \\
\hline Sands below the Acheulian level & $1.79 \pm 0.09$ & $2.44 \pm 0.13$ & $0.44 \pm 0.01$ \\
\hline
\end{tabular}

recommendations of Duval and Grün (2016) (Fig. 4).

Gamma-spectrometry was performed using high purity gamma-spectrometers in order to determine the radioelements contents of the dental tissues and sediments associated with the mandible (Table 1). U-series analyses have been then performed at MNHN (Paris) on the different dental tissues using alphaspectrometry according to the protocol developed by Qingfeng Shao (Shao et al., 2011) (Table 2) (Vietti, 2016).

The ESR/U-series ages were calculated using "combined US and AU" program. The following parameters were used in order to obtain an age: the contents-doses conversion factors of Adamiec and Aitken (1998) were used; beta-attenuation was calculated with Monte Carlo approach (from Brennan et al., 1997); a k-value of $0.13 \pm 0.02$ was used for enamel (from Grün and KatzenbergerApel, 1994); as in situ measurements were not realised in 1998, gamma dose-rate was calculated using the radioelements content of the Acheulian level, overlying and underlying sediments, whereas beta dose was calculated using only the sediments in close association with the tooth; cosmic-dose rate was calculated according to Prescott and Hutton $(1994 a, b)$ formulae, the water content was fixed at $0 \% \mathrm{wt}$ for enamel, $7 \%$ wt for dentine and for the $15 \%$ wt sediment, the Rn-loss was calculated combining the gamma- and alpha-spectrometry results (Bahain et al., 1992). The uncertainty on the ESR/U-series ages was calculated with Monte Carlo approach (Shao et al., 2014).

\section{Results}

\subsection{Fontana Ranuccio}

\subsubsection{Lithostratigraphy and geochemical composition of the pyroclasts}

The site of Fontana Ranuccio is located on the left side of the Fosso delle Mole stream, which drains the relatively wide valley of the small Costa Croce catchment (Fig. 5a). Based on litho-morphopedological features, the outcropping succession was subdivided in 5 either para-concordant or unconformity bounded stratigraphic units (Unit FR1 to Unit FR5; Fig. 5b).

Unit FR1 consists of 2 m-thick (base not outcropping) purple, massive, ash-supported pyroclastic deposits with cm-size blackishreddish scoria clasts.

Unit FR2 is a $1-2$ m-thick volcanoclastic deposits containing in its upper portion a dm-thick ash fall deposit (FR2a; Fig. 5). A thin palaeosol affects the top of the Unit FR2. The scoria fragments from the basal part of FR2a fallout layer have a foiditic composition (Fig. 6; Table 3; Supplementary Table S1) that is a diagnostic feature of the Colli Albani pyroclastics (e.g., Giaccio et al., 2013).

Table 2

U-series data (alpha-spectrometry) obtained for the dated tooth from Isoletta (Vietti, 2016).

\begin{tabular}{llllll}
\hline Sample & Tissue & ${ }^{238} \mathrm{U}(\mathrm{ppm})$ & ${ }^{230} \mathrm{Th} /{ }^{232} \mathrm{Th}$ & ${ }^{234} \mathrm{U} /{ }^{238} \mathrm{U}$ & ${ }^{230} \mathrm{Th} /{ }^{234} \mathrm{U}$ \\
\hline ISOL1401 & dentine & $149.68 \pm 4.05$ & 105.64 & $1.28 \pm 0.03$ & $0.87 \pm 0.04$ \\
(IPH-2014-28) & enamel & $1.65 \pm 0.07$ & 31.34 & $1.32 \pm 0.06$ & $0.95 \pm 0.06$ \\
\hline
\end{tabular}

Unit FR3 is a dm-thick, lenticular shape, discontinuous primary pyroclastic flow deposits made of blackish-greyish, ash and fine lapilli, leucite-bearing scoria.

Unit FR4, which is the archaeological horizon, is a $1.5 \mathrm{~m}$-thick volcanoclastic deposit mainly derived from the reworking of the underlying FR3 pyroclastic unit.

Unit FR5, unconformably overlying on Unit FR4 and locally reaching the thickness of ca. $4 \mathrm{~m}$, is a brownish-yellowish lithified pyroclastic deposit (tuff), previously recognized as Tufo Lionato (Biddittu et al., 1979).

\subsubsection{Volcanological and tephrochronological interpretation}

The overall lithological and geochemical features described above allow us to frame the Fontana Ranuccio succession within the well-established stratigraphy and geochronology of the nearby Colli Albani volcanic district (e.g., Marra et al., 2009).

Based on their general lithological features and stratigraphic order, the primary pyroclastic flow unit FR1, FR3 and FR5 can be respectively attributed to the Pozzolane Rosse ( $457 \pm 7$ ka, Karner et al., 2001; $457 \pm 2 \mathrm{ka}$, Giaccio et al., 2013), the Pozzolane Nere (407 \pm 2 ka, Karner et al., 2001; Marra et al., 2009), and Villa Senni eruptive successions ( $365 \pm 4 \mathrm{ka}$, Marra et al., 2009), of which the Tufo Lionato constitutes the main unit (e.g., Marra et al., 2009). As matter of fact, the succession including, from the bottom to top, the Pozzolane Rosse (Unit FR1), Pozzolane Nere (FR3) and Villa Senni (FR5), replicates the stratigraphic order of the three major eruptive units from the Colli Albani caldera recognizable on regional scale (e.g., Marra et al., 2009). This also allows us the attribution of the Unit FR2 to the so-called "Conglomerato Giallo", a volcanosedimentary stratigraphic units that regionally occurs between the Pozzolane Rosse and Pozzolane Nere pyroclastic units and that matches the MIS 11 San Paolo Unit of the Roman area (Karner et al., 2001). The youngest population of crystals containing in this volcano-sedimentary yielded the age $437 \pm 32 \mathrm{ka}$, which provide a terminus post quem for its deposition (Marra et al., 2009).

The fallout unit FR2a, in the uppermost portion of FR2, can be thus ascribed to the temporal range of the San Paolo Unit or MIS 11 period. In terms of chemical composition, the scoria fragments of FR2a fallout are characterised by a peculiar low $\mathrm{K}_{2} \mathrm{O} / \mathrm{Na}_{2} \mathrm{O}$ ratio $(<1$; Fig. 6) and, with exception of the MgO content, almost matches the composition of glass from the Pozzolane Nere eruptive unit. Based on these stratigraphic and geochronological constraints and taking into account its chemical affinity with glass from the Pozzolane Nere fallout (Table 3), the FR2a can be interpreted as a precursor of the Pozzolane Nere eruption, likely occurred shortly before the main explosive event.

\subsubsection{Comparison and correlation with stratigraphy from previous studies}

In previous investigations (Biddittu et al., 1979; Naldini et al. 2009), the stratigraphic succession of Fontana Ranuccio was subdivided in different pedo-stratigraphic units. Based on the lithological descriptions and chronological constraints provided in these studies, the five units distinguished in this study can be correlated to the previous ones as summarized in Table 4. From this 


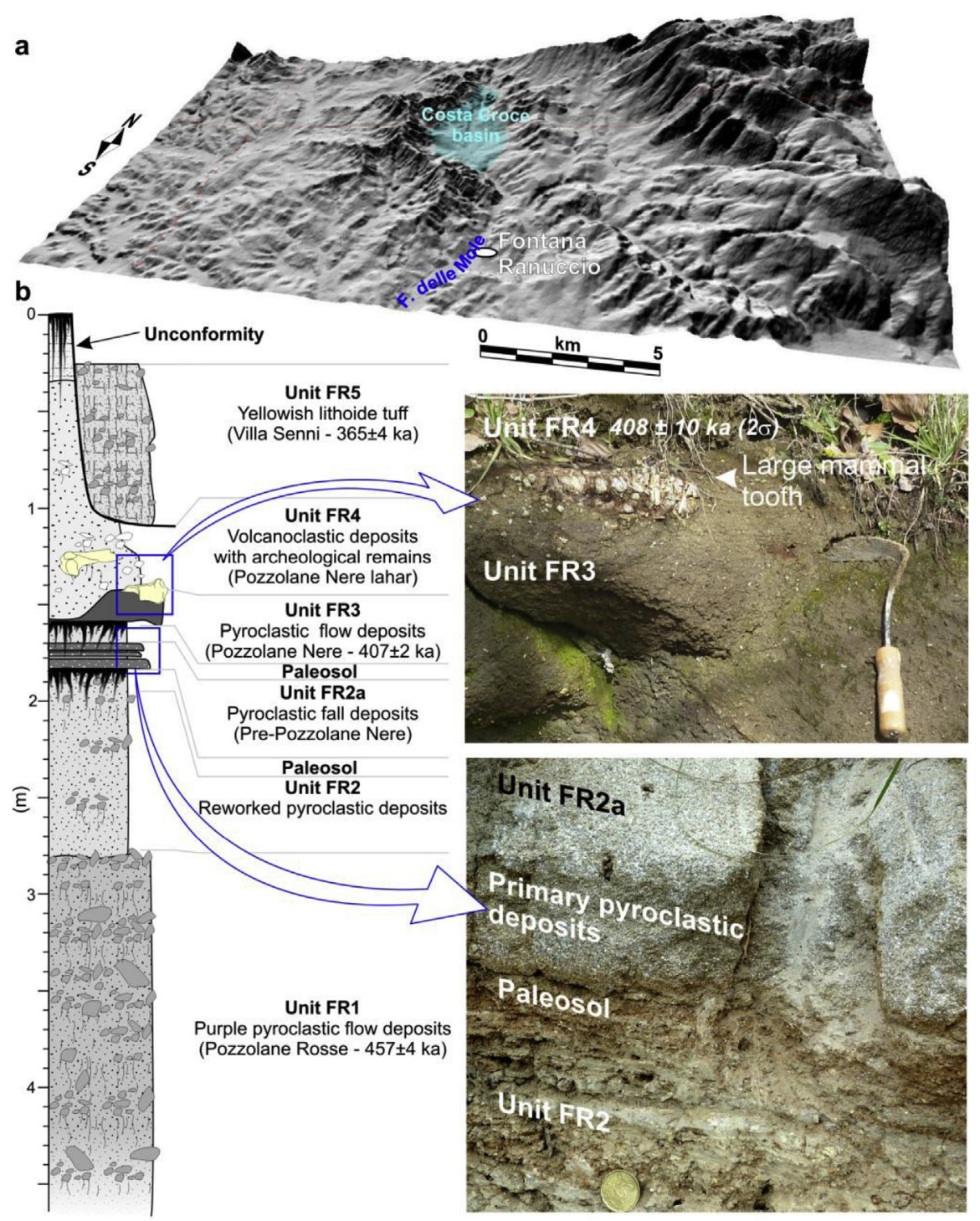

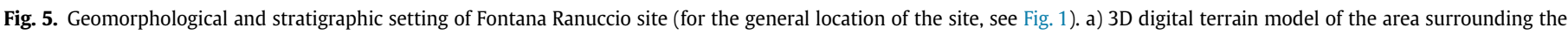

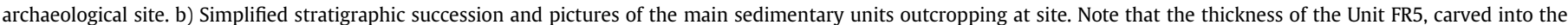
older ones, is not to scale and it can be on the order of ca. $4 \mathrm{~m}$.

comparison, a major chronological difference emerges for the horizon containing the archaeological and palaeontological remains (Unit FR4 or Level 10; Table 4); i.e., ca 407 ka vs. ca. 458 ka (Table 4). This difference can be justified by considering the position of the sample dated by Biddittu et al. (1979), which was collected at the bottom of the archaeological horizon. Indeed, the K/Ar dating of this sample precisely matches the age of the Pozzolane Rosse units (Unit FR1; Table 4), which, as reworked material, also composes the volcanoclastic Unit FR2. So, we argue that the first sample dated at $458 \pm 12$ ka (Biddittu et al., 1979) was actually collected from Unit FR2, and that this age was obtained on the leucite crystals from the underlying reworked Pozzolane Rosse unit.

\section{2. ${ }^{40} \mathrm{Ar} /{ }^{39} \mathrm{Ar}$ results}

${ }^{40} \mathrm{Ar} /{ }^{39} \mathrm{Ar}$ ages were calculated using the total decay constant of Steiger and Jäger (1977) and the standard ACs-2 at $1.193 \mathrm{Ma}$ (Nomade et al., 2005). However, considering all recent discussions and debates about ${ }^{40} \mathrm{Ar} /{ }^{39} \mathrm{Ar}$ methods calibrations (standard age and/or total decay constant, see details in Niespolo et al., 2016) we also put in supplementary data all our ages recalculated using the optimized calibration of Renne et al. (2011) (i.e. ACs-2 at 1.189 Ma; see for details Niespolo et al., 2016). Result of this new calibration corresponds to a decrease of the mean ages by $0.3 \%$ that, within the reported uncertainties, had no consequence on our interpretations. Detailed analytical data and procedural blanks associated could be found in supplementary dataset, Tables S3-S9. Weighted mean ages and full external uncertainties are calculated using IsoPlot 3.0 (Ludwig, 2001) including the decay constant and the J flux value. To be relevant, a homogeneous crystal population should present a probability fit $(\mathrm{P})>0.1$. For a lower $(\mathrm{P})$ value population of interest is not considered homogeneous and potentially, reworks various eruptions. Inverse isochrones corresponding to our analyses demonstrate in all cases (except sample ESR 4, see below) an initial ${ }^{40} \mathrm{Ar} /{ }^{36} \mathrm{Ar}$ ratio compatible with the atmospheric one (298.56; Lee et al., 2006) confirming the absence of argon excess in our samples. Results obtained for each sample are presented as probability diagrams in Fig. 7 (Deino and Potts, 1990). 

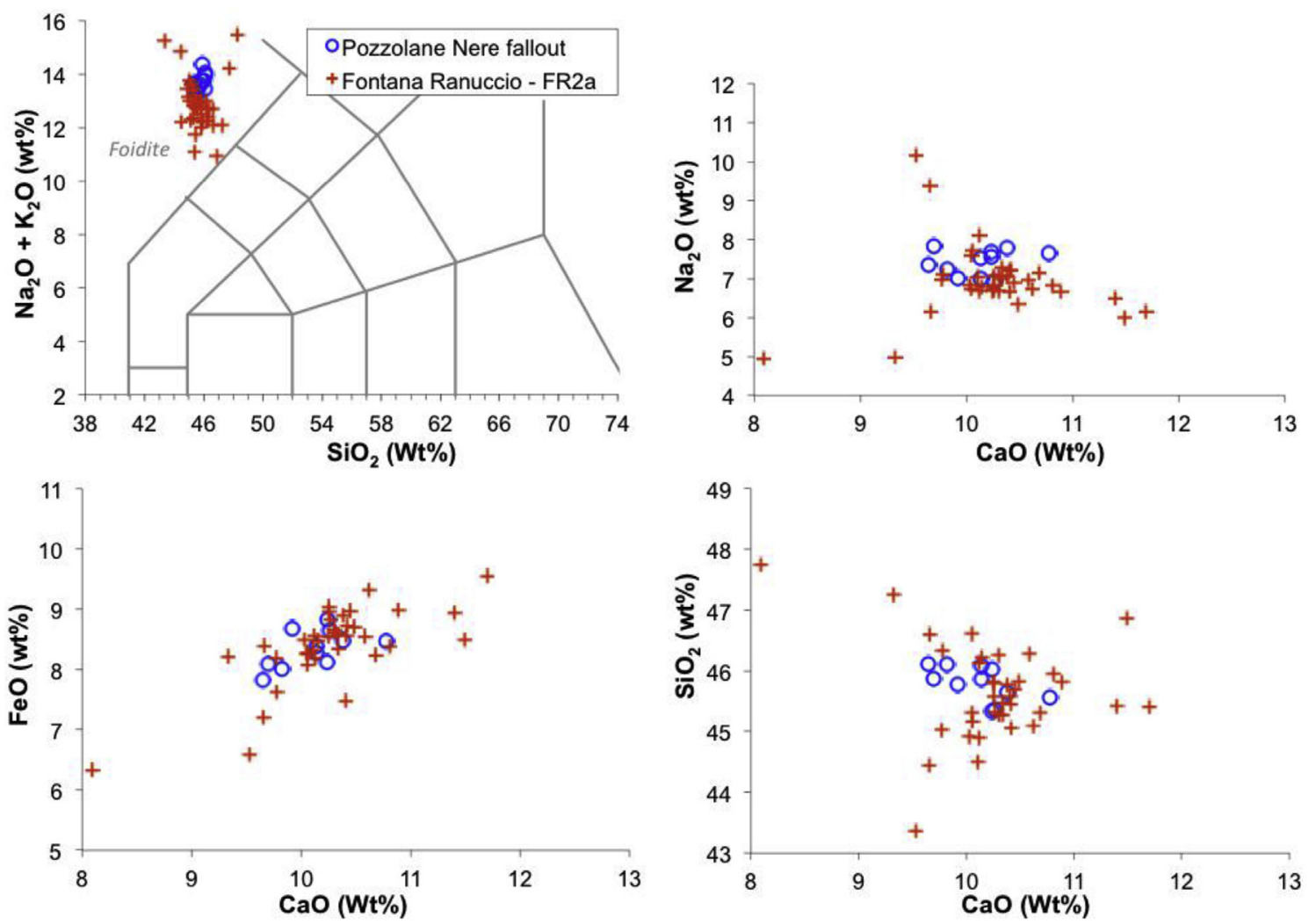

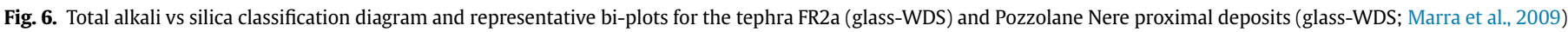

Table 3

Average major element compositions (normalized to $100 \% \mathrm{wt}$ ) of the glass in scoria fragments from the layer FR2a and the Pozzolane Nere proximal deposits (Marra et al., 2009).

\begin{tabular}{|c|c|c|c|c|c|c|}
\hline & \multicolumn{4}{|c|}{ Fontana Ranuccio FR2a } & \multicolumn{2}{|c|}{ Pozzolane Nere } \\
\hline & $\mathrm{n}=36$ & $s d^{\mathrm{a}}$ & $\mathrm{n}=2$ & $s d^{\mathrm{a}}$ & $\mathrm{n}=11$ & $s d^{\mathrm{a}}$ \\
\hline $\mathrm{SiO} 2$ & 45,63 & 0,74 & 48,05 & 0,39 & 45,80 & 0,29 \\
\hline $\mathrm{TiO} 2$ & 0,90 & 0,08 & 0,69 & 0,03 & 0,84 & 0,08 \\
\hline $\mathrm{Al} 2 \mathrm{O} 3$ & 19,64 & 0,82 & 20,70 & 0,77 & 18,36 & 0,17 \\
\hline $\mathrm{FeO}$ & 8,46 & 0,56 & 6,42 & 0,12 & 8,35 & 0,31 \\
\hline $\mathrm{MnO}$ & 0,45 & 0,44 & 0,30 & 0,03 & 0,31 & 0,07 \\
\hline $\mathrm{MgO}$ & 1,61 & 0,14 & 1,11 & 0,03 & 2,15 & 0,08 \\
\hline $\mathrm{CaO}$ & 10,32 & 0,51 & 7,74 & 0,50 & 10,11 & 0,33 \\
\hline $\mathrm{Na} 2 \mathrm{O}$ & 7,00 & 0,86 & 4,45 & 0,71 & 7,41 & 0,33 \\
\hline $\mathrm{K} 2 \mathrm{O}$ & 5,77 & 0,51 & 10,40 & 1,59 & 6,33 & 0,40 \\
\hline P2O5 & 0,21 & 0,04 & 0,15 & 0,04 & 0,34 & 0,06 \\
\hline $\mathrm{F}$ & 1,01 & 0,16 & 0,64 & 0,13 & 0,85 & 0,10 \\
\hline $\mathrm{Cl}$ & 0,33 & 0,10 & 0,27 & 0,12 & nd & - \\
\hline $\mathrm{SO} 2$ & 0,52 & 0,53 & 0,45 & 0,43 & 0,32 & 0,05 \\
\hline
\end{tabular}

a standard deviation.

1) Fontana Ranuccio: The obtained probability diagram is multimodal (Fig. 7). Identification of the juvenile crystal population is not straightforward, as two eruptions close in time seem to be mixed. The "unmixing" statistical test (Isoplot 3.0, Ludwig, 2001) allowed us to extract a population of five crystals that we considered as juvenile. Including other crystals in the weighted mean average calculation leads to an increase of the MSWD over 2.0 suggesting a heterogeneous population. Weighted mean age obtained for these five crystals is $408 \pm 10$ ka ( $2 \sigma$ full external error included) with a probability of 0.8 (see Table S3 supplementary dataset). The second eruption composed by also five crystals is centred at $415 \mathrm{ka}$. One older xenocryst is dated at around $440 \mathrm{ka}$.

2) Cava Pompi: for the palaeosol of Cava Pompi 8 crystals were measured (see Table S4 supplementary dataset). Diagram shows only one population suggesting that the soil developed on a primary volcanic deposit (Fig. 7). Weighted mean age obtained is $397 \pm 10 \mathrm{ka}$ ( $2 \sigma$ full external error included) with a probability of 1.

3) Isoletta and Lademagne (Ceprano basin)

- At Isoletta, three layers were dated. We analysed 12 sanidine crystals in the volcanic layer in which ESR 1 sample was collected. Eleven out of 12 crystals have statistically the same age (see Fig. 7 and Table S5 supplementary data) highlighting the primary nature of the volcanic material found in this sedimentary unit. The weighted mean age obtained is $403 \pm 8$ ka with a probability of 0.6 . The probability diagram for GA6Z level is also relatively simple with two main modes (see Fig. 6). Juvenile crystals population is made of ten sanidines allowing the calculation of a weighted mean age of $374 \pm 10 \mathrm{ka}(2 \sigma$ full external error included, see Table S6 supplementary dataset) with a probability of 0.2. Level corresponding to sample ESR $\mathbf{4}$ at the top of the stratigraphy is probably composed of various reworked volcanic eruptions as several modes are recorded (see Table S7 supplementary dataset). The two youngest crystals share a weighted mean age of $365 \pm 19 \mathrm{ka}$ with a probability of 0.8 . If we take into account the analytical uncertainties at $2 \sigma$, the ages obtained for GA6Z and ESR 4 are marginally different.

- At Lademagne, for layer Lad Inf 15 crystals were analysed. Probability diagram is very complex, as expected for a fluvial terrace. The youngest mode is composed by 7 of the 15 crystals measured (see Table S8 supplementary dataset). The weighted 
Table 4

Stratigraphy and tephrochronology of Fontana Ranuccio site compared with the previous stratigraphic scheme from Biddittu et al. (1979) and Segre Naldini et al. (2009).

\begin{tabular}{|c|c|c|c|c|c|}
\hline \multicolumn{3}{|l|}{ This Study } & \multicolumn{3}{|l|}{ Previous studies } \\
\hline \multirow[b]{2}{*}{ Site Stratigraphy } & \multirow[b]{2}{*}{ Regional stratigraphy } & \multirow[b]{2}{*}{${ }^{40} \mathrm{Ar} /{ }^{39} \mathrm{Ar}$ age $(\mathrm{ka} \pm 2 \sigma)$} & \multirow{2}{*}{$\frac{\text { Segre Naldini et al. (2009) }}{\text { Site Stratigraphy }}$} & \multirow{2}{*}{$\frac{\text { Biddittu et al. (1979) }}{\text { Site Stratigraphy }}$} & \\
\hline & & & & & $\mathrm{K} / \mathrm{Ar}$ age $(\mathrm{ka} \pm 2 \sigma)$ \\
\hline Unit FR5 & Villa Senni unit & $365 \pm 8^{+}$ & Level 13-14 & Unit $\mathrm{tl}_{2}$ & $366 \pm 9$ \\
\hline Unit FR4 & Pozzolane Nere lahar & $408 \pm 10^{\mathrm{a}}$ & Level 10 to 12 & Unit $2-3$ & $458 \pm 12$ \\
\hline Unit FR3 & Pozzolane Nere flow unit & $407 \pm 2^{\mathrm{b}}$ & Level 10 bottom & Unit 4 & \\
\hline Unit FR2a & Pre-Pozzolane Nere fall & - & - & Unit 6 & \\
\hline Unit FR2 & Conglomerato Giallo & $<437 \pm 32^{c}$ & Level 9 top & Unit 7 top & \\
\hline Unit FR1 & Pozzolane Rosse unit & $457 \pm 7^{c}$ & Level 9 bottom & Unit $10-7$ & \\
\hline
\end{tabular}

a This study.

b Marra et al. (2009).

c .Karner et al. (2001). Uncertainties are at $2 \sigma$.

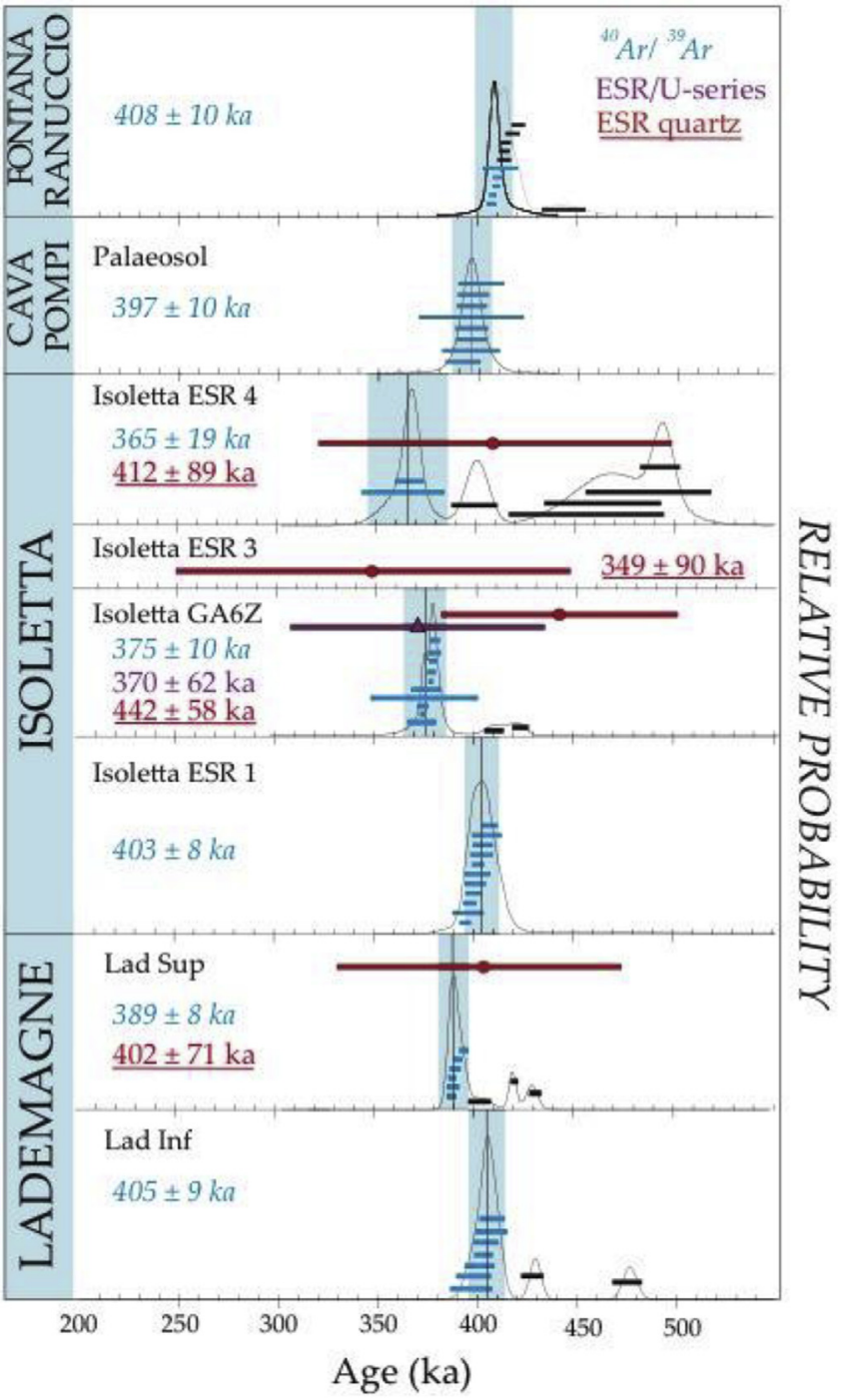

Fig. 7. Ages diagrams obtained by the different methods for Fontana Ranuccio, Cava Pompi, Isoletta, and Lademagne sites. The ${ }^{40} \mathrm{Ar} /{ }^{39} \mathrm{Ar}$ results are shown as probability diagrams and written in blue while the ages obtained by ESR/U-series (purple) and ESR on quartz (red) analyses are presented as points with their uncertainties. Detailed data are in supplementary dataset (Tables S3-S9). All error bars take into account the full external errors at $2 \sigma$. (For interpretation of the references to colour in this figure legend, the reader is referred to the Web version of this article.) mean age associated to the youngest population is $405 \pm 9 \mathrm{ka}$ with a probability of 0.4 (Fig. 7). Probability diagram for Lad Sup is also complex, with a youngest mode composed by 7 out of the 17 measured sanidines. A weighted mean age of $389 \pm 8$ ka, with a probability of 0.1 (see Fig. 7 and Table S9 supplementary dataset) is calculated for this population.

\subsection{ESR on bleached quartz}

At Isoletta, results obtained by ESR on quartz using $\mathrm{Ti}$ and $\mathrm{Al}$ centres are consistent (see Table 5). The age of the ESR 1 sample appears however as severely overestimated in comparison with the ${ }^{40} \mathrm{Ar} /{ }^{39} \mathrm{Ar}$ chronology. This overestimation seems to be linked to a very low annual dose rate reconstructed from its radioelements in the absence of in situ measurement. In addition, the results obtained using the two centres are distinct but both greater than 1 Ma. These different aspects lead us to not retain these results. For the other dated levels, the relatively large error ranges observed are explained by the quite poor quality of the growth curves (ESR intensity vs. irradiation dose) with $\mathrm{r}^{2}$ ranging between 0.97 and 0.98 . These curves, as well as an angular dependence observed for these samples, indicate heterogeneous samples, not allowing an ESR dating with great accuracy. Nevertheless, the results obtained are usable and in agreement with the other geochronological data for this site.

For GA6Z, ESR 3, ESR 4 and Lad Sup samples, the close $D_{E}$ obtained using the two centres for each sample allow us to give a weighted average age for each level, calculated from the $\mathrm{Ti}$ and $\mathrm{Al}$ results. Weighted mean ages are $442 \pm 58$ ka for Isoletta GA6Z sands, $349 \pm 90$ ka for ESR 3 sands, $412 \pm 89$ ka for ESR 4 sands and $402 \pm 71$ ka for Lad Sup sands.

\section{4. $E S R / U$-series}

Classical US model (Grün et al., 1988) cannot be applied on the Isoletta tooth, due to slight U-leaching evidence and AU model (Shao et al., 2011) was therefore used to calculate the ESR/U-series age (Table 6$)$. The present dating result is $370 \pm 31 \mathrm{ka}(1 \sigma)$ for the tooth ISOL1401. It seems to be coherent with ${ }^{40} \mathrm{Ar} /{ }^{39} \mathrm{Ar}$ dates and ESR ages obtained on optically bleached quartz for this Acheulian layer. It will be interesting in the future to integrate other studies, in order to clarify the chronology of the site, which is still subject of study in the Lower Palaeolithic scenario of Latium.

\subsection{Lithic series preliminary analysis}

\subsubsection{Fontana Ranuccio}

At Fontana Ranuccio, the tool-bearing level FR4 (Fig. 5) yielded 
Table 5

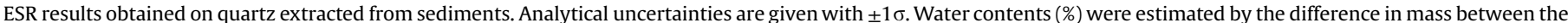

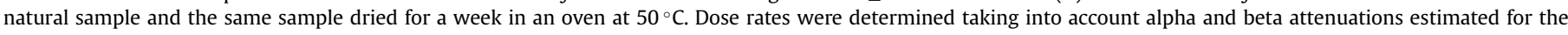

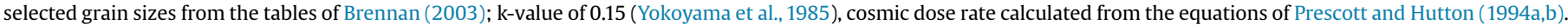

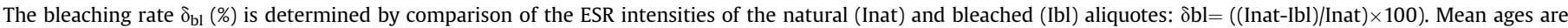
weighted average calculation using Isoplot software.

\begin{tabular}{|c|c|c|c|c|c|c|c|c|c|c|c|}
\hline & & $\begin{array}{l}\mathrm{D} \alpha \\
\mu \mathrm{Gy} / \mathrm{a}\end{array}$ & $\begin{array}{l}\mathrm{D} \beta \\
\mu \mathrm{Gy} / \mathrm{a}\end{array}$ & $\begin{array}{l}D \gamma \\
\mu G y / a\end{array}$ & $\begin{array}{l}\text { Cosmic } \\
\mu \mathrm{Gy} / \mathrm{a}\end{array}$ & $\begin{array}{l}\mathrm{W} \\
\%\end{array}$ & $\delta_{\mathrm{bl}} \%$ & $D_{a} \mu G y / a$ & $\begin{array}{l}D_{e} \\
G y\end{array}$ & $\begin{array}{l}\text { Ages } \\
\text { (ka) }\end{array}$ & Mean Ages (ka) \\
\hline \multirow[t]{2}{*}{ ESR 1} & $\mathrm{Ti}$ & $19 \pm 1$ & $190 \pm 11$ & $168 \pm 10$ & $24 \pm 1$ & 15 & 48 & $233 \pm 15$ & $715 \pm 75$ & $1786 \pm 327$ & \\
\hline & $\mathrm{Al}$ & $19 \pm 1$ & $190 \pm 11$ & $168 \pm 10$ & $24 \pm 1$ & 15 & 48 & $233 \pm 15$ & $462 \pm 24$ & $1154 \pm 109$ & \\
\hline \multirow[t]{2}{*}{ GA6Z } & $\mathrm{Ti}$ & $57 \pm 2$ & $1786 \pm 36$ & $1008 \pm 28$ & $33 \pm 2$ & 14 & 42 & $1876 \pm 45$ & $1155 \pm 110$ & $401 \pm 59$ & $442 \pm 58$ \\
\hline & $\mathrm{Al}$ & $57 \pm 2$ & $1786 \pm 36$ & $1008 \pm 28$ & $33 \pm 2$ & 14 & 42 & $1876 \pm 45$ & $1315 \pm 62$ & $456 \pm 34$ & \\
\hline \multirow[t]{2}{*}{ ESR 3} & $\mathrm{Ti}$ & $30 \pm 2$ & $497 \pm 20$ & $354 \pm 16$ & $53 \pm 3$ & 12 & 46 & $581 \pm 26$ & $314 \pm 73$ & $336 \pm 66$ & $349 \pm 90$ \\
\hline & $\mathrm{Al}$ & $30 \pm 2$ & $497 \pm 20$ & $354 \pm 16$ & $53 \pm 3$ & 12 & 46 & $581 \pm 26$ & $338 \pm 60$ & $362 \pm 64$ & \\
\hline \multirow[t]{2}{*}{ ESR 4} & $\mathrm{Ti}$ & $20 \pm 1$ & $303 \pm 12$ & $220 \pm 10$ & $101 \pm 5$ & 15 & 45 & $425 \pm 16$ & $275 \pm 25$ & $426 \pm 59$ & $412 \pm 89$ \\
\hline & $\mathrm{Al}$ & $20 \pm 1$ & $303 \pm 12$ & $220 \pm 10$ & $101 \pm 5$ & 15 & 45 & $425 \pm 16$ & $252 \pm 40$ & $391 \pm 72$ & \\
\hline \multirow[t]{2}{*}{ Lad Sup } & $\mathrm{Ti}$ & $77 \pm 3$ & $980 \pm 35$ & $\begin{array}{l}876 \pm 31 \\
\text { I.S.919 } 52\end{array}$ & $111 \pm 6$ & 5 & 44 & $2088 \pm 70$ & $831 \pm 70$ & $\begin{array}{l}398 \pm \\
51\end{array}$ & $402 \pm 71$ \\
\hline & $\mathrm{Al}$ & $77 \pm 3$ & $980 \pm 35$ & $\begin{array}{l}876 \pm 31 \\
\text { I.S.919 } 52\end{array}$ & $111 \pm 6$ & 5 & 44 & $2088 \pm 70$ & $847 \pm 100$ & $\begin{array}{l}406 \pm \\
51\end{array}$ & \\
\hline
\end{tabular}

Table 6

ESR/U-series data and age obtained for the Isoletta sample at $1 \sigma$ uncertainties.

\begin{tabular}{|c|c|c|c|c|c|c|}
\hline Sample & Tissue & $\begin{array}{l}\mathrm{U} \\
(\mathrm{ppm})\end{array}$ & $\mathrm{D}_{\mathrm{E}}(\mathrm{Gy})$ & $\begin{array}{l}\text { U-uptake } \\
\text { Parameter } \\
\text { (p- or } n \text {-factor) }\end{array}$ & $\begin{array}{l}D_{a} \\
(\mu G y / a)\end{array}$ & ESR/U-series AU age (ka) \\
\hline ISOL1401 & $\begin{array}{l}\text { dentine } \\
\text { enamel }\end{array}$ & $\begin{array}{l}149.68 \pm 4.05 \\
1.65 \pm 0.07\end{array}$ & $1151 \pm 33$ & $\begin{array}{l}-0.5780 \pm 0.0634 \\
-0.0031 \pm 0.0004\end{array}$ & $3110 \pm 257$ & $370 \pm 31$ \\
\hline
\end{tabular}

three bifaces on lava and one on flint associated to many microlithic artefacts (on grey flint), choppers or chopper-cores and cores made of flint and lava (Ascenzi et al., 1996; Naldini et al., 2009). Most of the small artefacts (average length of $20 \mathrm{~mm}$ ) are debris of "débitage" and many scrapers and denticulates has a deep and invasive retouch (Biddittu et al., 1979). Technological analysis indicates a flaking by unipolar or centripetal removals and deep scars on the cores. The complete biface on lava is thick and symmetrical. It was made by large and abrupt removals on the whole surfaces.

\subsubsection{Isoletta}

The series of Isoletta level GA6Z is composed by 12 limestone bifaces, one large retouched limestone flake and some bifacial flint cores. Bifaces are elongated, partially or totally shaped, made by deep and large removals, and rarely associated to final retouches. The maximum thicknesses of the tools are mainly at the base or centre of the pieces. Technological groups of bifaces are highlighted by the invasiveness and intensity of the shaping, resulting on more or less asymmetrical tools, on pebbles, half-pebbles or large flakes. Tools $(n=4)$ were made by large removals on the half or two-third parts of the piece preparing convergent edges or by large and short removals on the whole volume $(n=11)$.

\subsubsection{Lademagne}

The assemblages of the two archaeological levels of Lademagne site were studied separately.

Upper archaeological level - The "débitage" activity is attested at Lademagne by limestone-cores made on large and thick pebbles (100-200 mm long). The core technology is unifacial and unipolar ("semi-tournant"), orthogonal or on multiple surfaces.

Twenty-five bifaces were recovered from this level. They are in limestone of various qualities (Fig. 8). The quality of this raw material could explain in some cases the high frequency of hinged scars. Only few bifaces are in flint. Two groups can be individualised: (1) - tools with a general bifacial management (60\%), (2) partial bifacial tools, mainly on flakes or flat pebbles with preserved cortical backs (40\%). The first group, including the bifaces made in flint, is composed of short or elongated bifaces (150 and $200 \mathrm{~mm}$ long) made by invasive series of removals. The edges are often rectified by a final retouch and the cross-section is symmetrical (alternate shaping) or plano-convex (face by face shaping). The bases of these industries are sometimes unworked, with a back (butt of a flake?) and thick. Tips are made by removals including into the general management, by one large transversal removal or small secondary retouches. For the partial bifacial tools, one or the two edges of the tools are shaped by short removals given a planoconvex cross-section. Some tools with a back, look like bifacial scrapers.

Lower archaeological level - "débitage" is also attested in the lower level for polyhedral and unifacial cores made on big blocks and pebbles (limestone and flint).

Among the end-products of "débitage", we may mention one "Levallois-type" flake demonstrating some evidences of preparation of lateral convexities on the core. However, as no Levallois core was demonstrated at Lademagne, we cannot confirm the real practice and knowledge of this core technology.

This series includes fourteen bifacial tools and limestone bifaces (except one flint biface) of poor quality (pieces with a transversal cutting edge and a total bifacial shaping, large flakes with a partial management and numerous bifaces with a bifacial global management). Bifaces showing a general bifacial management are mainly elongated (150-200 mm long), made by several series of large and deep removals and sometimes a final retouch. Crosssections of the tips are always plano-convex and sometimes symmetrical at the base. Edges are sinuous. The shorter bifaces show a round or transversal tip while the longer tools are carefully worked with a pointed extremity. The biface made of flint is one of the most worked tools of the series.

\subsubsection{Campogrande}

At Campogrande, several series were also studied according to their stratigraphic position and locality. 

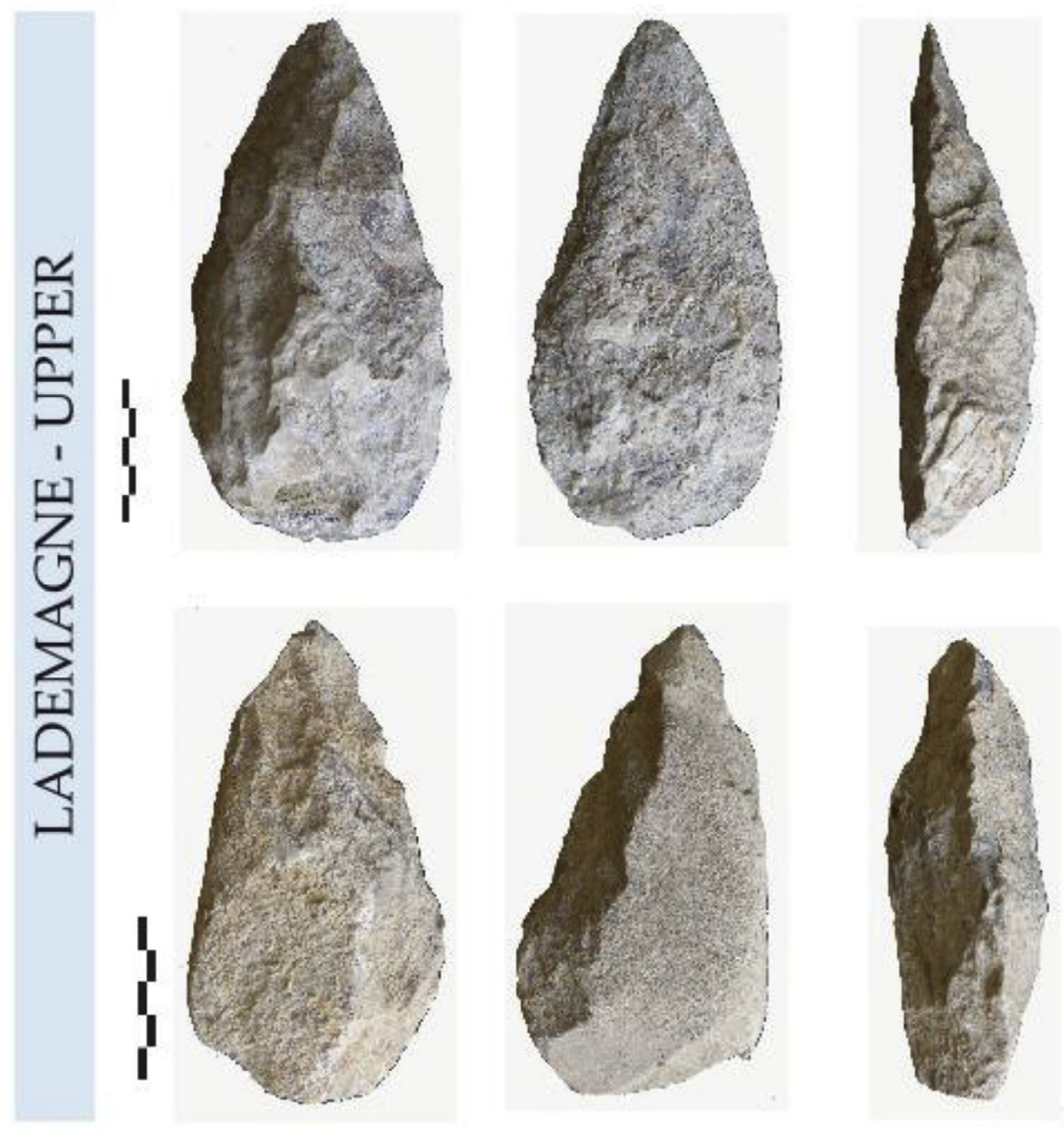

Fig. 8. Examples of bifacial tools from the upper archaeological level of Lademagne.

CG 10 Upper archaeological level - Cores and/or chopper-cores are made on small flint nodules/pebbles $(50 \mathrm{~mm})$ and limestone pebbles of poor quality with an orthogonal or unifacial unipolar "débitage". In this series a total twenty-two limestone heavy-duty tools was discovered. Except one thick pointed scraper (rabottype), two categories of heavy-duty tools can be distinguished:

(1) - Elongated plano-convex bifaces $(\mathrm{n}=5)$ (200 mm long) made by invasive removals never retouched. Edges are sinuous. Tips are always thin whereas the proximal or middle part of the biface is thick.

(2) - Partial bifacial tools on flakes $(n=16)$. This category includes short and elongated diversified asymmetrical pieces (from 110 to $210 \mathrm{~mm}$ ) with a shaping mainly on the upper part of the tools. Some pieces demonstrate only the tip and one edge worked.

CG 10 Intermediate archaeological level - Except some minimally flaked cores on small flint nodules (less than $50 \mathrm{~mm}$ long), this series is composed by both heavy-duty and light-duty components. The light-duty component includes micro-tools made on limestone pebbles and micro-flint nodules (30-50 mm long), little shaped. Heavy-duty tools are composed of some thick rabots and scrapers on a limestone half-pebble, and three bifaces. For the bifaces:
(1) One is minimally shaped with a thick base. Shaping concerns the whole volume with numerous and abrupt removals. The cutting edges are sinuous without final retouches;

(1) - One is an asymmetrical elongated biface in limestone largely worked, finally retouched on the edges;

(2) -There is one symmetric biface in limestone, made on halfpebbles). The shaping is little invasive.

CG 10 Lower archaeological level-not examined in this work.

CG 9 Upper archaeological level - This series totals one thick bifacial core and eleven bifaces. They are all on limestone and diversified in size (80-180 $\mathrm{mm}$ long) suggesting three groups:

(1) - Short symmetric bifaces completely or partially worked $(n=2)$;

(2) - Plano-convex partial bifacial tools with sometimes a back $(n=3)$;

(3) - Asymmetric tools with large removals on the flattest surface and a partial shaping on the opposite $(n=6)$.

\section{Discussion}

\subsection{A new chronological framework}

The results obtained by the different dating techniques allow us to accurately constrain the hominin occupation levels from the 
studied sites of the Frosinone province. The results are mostly complementary and in good agreement. Our multimethod approach highlights the potential of combining various techniques based on different physical principal to accurately date Quaternary archaeological sequences. At Fontana Ranuccio, the ${ }^{40} \mathrm{Ar} /{ }^{39} \mathrm{Ar}$ age $(408 \pm 10 \mathrm{ka}, \mathrm{FR} 4)$ and the chemical analyses on glass shard from Unit FR2a (Fig. 5) lead us to correlate these volcanic activities to the Pozzolane Nere eruptive cycle from the Colli Albani (Fig. 5). The ${ }^{40} \mathrm{Ar} /{ }^{39} \mathrm{Ar}$ age indicates that Fontana Ranuccio archaeological remains are embedded into volcanoclastic sediments that could be interpreted as a "lahar" deposit triggered after the Pozzolane Nere (PN) eruption.

The PN is dated to $407 \pm 8$ ka (95\% of probability; Karner et al., 2001, Fig. 10) and this is in perfect agreement within uncertainties to the age we obtained on the Fontana Ranuccio lahar (408 \pm 10 ka, Fig. 2 and 10). Fontana Ranuccio palaeontological and archaeological assemblages are now well constrained to the MIS 11 climatic optimum according to the comparison of the ${ }^{40} \mathrm{Ar} /{ }^{39} \mathrm{Ar}$ age with the Ohrid pollen diagram (Sadori et al., 2016) and with Mediterranean marine records (Girone et al., 2013; Capotondi et al., 2016) (Fig. 10), and not to the MIS 13 as suggested previously (Biddittu et al., 1979). Our new results also suggest that the age of $458 \pm 12$ ka $(2 \sigma$ analytical uncertainties, Biddittu et al., 1979) obtained by ${ }^{40} \mathrm{~K} /{ }^{40} \mathrm{Ar}$ could have been corrupted by older leucites xenocrysts, likely from the underlying PR deposits (layer FR1; Fig. 5), dated to $456 \pm 3$ ka or $457.4 \pm 1.7$ ka (Karner et al., 2001; Giaccio et al., 2013). It shows once again that dating pyroclastic deposits using the ${ }^{40} \mathrm{~K} /{ }^{40} \mathrm{Ar}$ method is not appropriate and could lead to spurious older ages. The other possible and most probable explanation for this ancient age is the fact that the sample dated in 1979 by Biddittu et al. may have been, by mistake, sampled in Unit FR2 that is associated to the Pozzolane Rosse unit ( $457 \mathrm{ka}$ ). Indeed, the thicknesses of the various sedimentary layers recorded at Fontana Ranuccio vary in the studied area and in some places Unit FR4 is directly in unconformity on Unit FR2.

Isoletta and Lademagne, located only $5 \mathrm{~km}$ each other and previously interpreted as part of the same fluvial unit, display very coherent results. ${ }^{40} \mathrm{Ar} /{ }^{39} \mathrm{Ar}$, ESR on bleached quartz and ESR/Useries data gave in fact all identical ages within uncertainties (Figs. 7 and 10). They clearly demonstrate that the two sites are coeval spanning the 405-375 ka period (MIS 11 to MIS 11/10 transition (Fig. 10). The two oldest units in these two sites share an identical age ( $405 \pm 9 \mathrm{ka}$ and $403 \pm 8 \mathrm{ka}$, for Lademagne and Isoletta respectively) suggesting that these sequences and archaeological remains can be assigned to the end of MIS 11 interglacial and to the MIS 11/MIS 10 glacial transition (Fig. 10). It is worth mentioning that the regional palaeoenvironmental records from Ohrid (Sadori et al., 2016) and ODP 975 (Mediterranean Sea, Girone et al., 2013) both sea surface temperature and pollen records, although punctuated by short stadial events, indicate relative warm and wet conditions similar to typical "interglacial" conditions during most of the MIS 11 period. It is only after the period that chronologically matches the Tufo Lionato eruption age (TL, $365 \pm 4$ ka; Fig. 10) that the climate in the Mediterranean region changed toward drier and colder conditions, as clearly shown by the sharp decrease of arboreal pollen in the Lake Ohrid. The ages obtained in both Lademagne and Isoletta suggest that the lithic and palaeontological assemblages are slightly younger than those found at Fontana Ranuccio, as all archaeological layers are found in units younger than $405 \pm 9$ ka and $403 \pm 8 \mathrm{ka}$, respectively. On the whole, the chronological similarity and the geographic proximity of the Lademagne and Isoletta suggest that these two sites are contemporaneous. For these two sites, the multimethod approach has been essential to understand the chronological framework of the archaeological sequences, as we could not find any primary volcanic deposit. Our ESR ages have thus reinforced the dates provided by the ${ }^{40} \mathrm{Ar} /{ }^{39} \mathrm{Ar}$ technique on reworked pumices.

The age of Cava Pompi succession is more difficult to assess as we only have one ${ }^{40} \mathrm{Ar} /{ }^{39} \mathrm{Ar}$ age (i.e., $397 \pm 10 \mathrm{ka}$ ) for the palaeosol formation below the human occupation layer. As human occupation (i.e., archaeological level 3 ) is stratigraphically just above this palaeosol (Fig. 2), these remains are younger than $397 \pm 10 \mathrm{ka}$ (see Figs. 2 and 7). However, taking into account the pedostratigraphic setting, the faunal remains and our new chronological information, we could attribute the soil formation to the late MIS 11 pulling toward the hypothesis that the Cava Pompi occupation was contemporaneous with the late MIS 11 and/or MIS 11-10 transition periods, that is chronologically close to the other studied sites. We therefore consider hereafter Cava Pompi as coeval to the other investigated sites.

The new chronological framework summarized in Fig. 10 shows that the occupations of Fontana Ranuccio, Lademagne, Isoletta, and Cava Pompi are pene-contemporaneous. They all started during the first part of the MIS 11, that is characterised by stable wet and warm interglacial conditions, and extended over the second part of MIS 11 (climatically more unstable) until the transition toward the MIS 10 , which marks the definitive establishment of full glacial conditions (Fig. 10). It corresponds to a brief period of time comprised between $408 \pm 8 \mathrm{ka}$ and $375 \pm 10 \mathrm{ka}$ (i.e., $33 \pm 13 \mathrm{ka}$ ).

Our geochronological results legitimate thus the intercomparison between palaeontological and lithic assemblages recorded in these sites. Concerning the Campogrande localities it is worth mentioning that the CG 10 and CG 9 assemblages are all deposited above the volcanic layer dated by Nomade et al. (2011) to $353 \pm 8 \mathrm{ka}$ and thus younger than this age. These assemblages are therefore substantially younger than those considered in this study and likely developed under different environmental conditions (i.e., drier/colder).

The regional palaeoclimatic record (Girone et al., 2013) showed in Fig. 10 suggests, like in several studies (e.g., Conard et al., 2015; Oliveira et al., 2016; Moncel et al., 2017), that the MIS 11 was an unusually long "interglacial" period followed by a relatively short glacial period (i.e. MIS 10). According to Moncel et al. (2016), the short duration of the MIS 10 could be responsible for a poor documentation of sediments related to this glacial period in Europe. However, archaeological remains and testimonies of the continuous occupation of the Frosinone region during MIS 10 period are found (e.g., Campogrande or Ciampate del Diavolo footsteps; Nomade et al., 2011; Scaillet et al., 2008). Pollen diagram available for the Lake Ohrid (Albania/Macedonia, Sadori et al., 2016) supports a short MIS 10 with no significant reduction of the arboreal taxa suggesting a persistence of woodland and temperate environment in the Mediterranean during this stage. In several studies the Mediterranean area has been shown to be a warm spot during the glacial periods (Tzedakis, 2007; Orain et al., 2013). These particular conditions could explain the attractiveness of the territory for the large mammal herds and persistence of occupations of hominid populations.

The peculiar palaeoenvironmental conditions of the Latium, jointly with the opportunity that this region offers of applying robust geochronological techniques, make it a key-area in Europe for understanding the cultural and biological evolution of the hominins and their interplay with climate-environmental changes during the MIS 11 and MIS 10 periods. This unique and favourable circumstances are also applied to palaeontological studies, that can equally benefit of these numerous sites that are now precisely and accurately dated in order of refining the MIS 11-MIS 10 biochronology of the Central Italy, as shown in recent studies (e.g., Marra et al., 2014; Marra et al., 2016). 
6.2. Regional and extra-regional comparison: preliminary hints on the Acheulian variability

In order to frame our finding on a wider scale, we compare the present results with the other regional and extra-regional subcoeval Acheulian sites. By Acheulian groups we consider hominin groups able to perform bifacial technology. The quantity of artefacts collected at Campogrande (CG), Isoletta (GA6Z) and Lademagne localities differs, with globally little series when compared to other localities such as Colle Avarone or Selvotta ( $600 \mathrm{~m}$ from Ceprano) (Biddittu and Segre, 1977). Despite the low number of artefacts, technological and morphological features demonstrate common strategies in all the investigated records of the Frosinone province, suggesting regional traditions that seems to persist over the MIS 11 interglacial and the MIS 10 glacial period (i.e. $~ 50 \mathrm{ka}$ ). Despite the fact that pieces are mostly made on poorly preserved local limestone with smooth edges and often covered by patches of breccia, making impossible the identification of land-use patterns over territories, we are able to underline some common intra-site features. Retouched fragments of large mammal bones from Isoletta (GA6Z), Fontana Ranuccio and Campogrande suggest more similar types of occupation than those of the slightly younger sites of Torre in Pietra (Villa et al., 2016) and maybe Castel di Guido, showing the exploitation of elephants and other large herbivores carcasses and bones fragments (Biddittu et al., 1979; Biddittu and Segre, 1982; Ascenzi et al., 1996; Naldini et al., 2009; Anzidei et al., 2012; Boschian and Saccà, 2015). Lithic series are mainly made on finegrained limestone generally of poor quality, punctually associated to flint, quartzite and quartz of higher quality. Some bifaces are made on large flakes obtained from cobbles that were rarely abandoned, except in the upper level of Lademagne. On these sites, types of raw materials differ between the pieces produced by core technology or by shaping; limestone is the main one for bifaces and heavy-duty component, while flint and quartz are mainly employed for flaking. Few bifaces made on flint and quartzite were however found at Campogrande and Lademagne. Core technologies demonstrate common technological rules with cores basically small, on flint nodules, except at Lademagne where big-size limestone cores are found. Cores are never prepared and the "débitage" is systematically related to the support form. It affects one or two faces (unifacial, bifacial or orthogonal) with unipolar removals. Some round pebbles produced "slices". Levallois core technology is absent, except at Lademagne where one "Levalloistype" flake was found in the lower archaeological occupation level (see Figs. 2 and 9). Taking into account our new chronological data, this "Levallois-type" flake is coeval or older than the main volcanic eruption recorded in the level Lad Inf. and dated by ${ }^{40} \mathrm{Ar} /{ }^{39} \mathrm{Ar}$ at
$405 \pm 9 \mathrm{ka}$. This flake could indicate a punctual practice of this technology like recently highlighted in the neighbour site of Guado San Nicola (Molise) dated to MIS 11/10 transition (Peretto et al., 2016; Pereira et al., 2016) and in the Acheulian site of Rosaneto (Calabria) (Biddittu et al., 1984). The presence of this kind of technology supports the long transition phase hypothesis between the Lower and Middle Palaeolithic and the relatively long coexistence of these two entities in Europe but also in Asia and Africa during this period (Richter et al., 2017; Akilesh et al., 2018).

On the whole, the core technology of our series is similar to what is observed at Torre in Pietra (layer " $\mathrm{m}$ "), dated to the MIS 10/ MIS 9 transition (Villa et al., 2016), but also to the younger butchery site of La Polledrara di Cecanibbio (MIS 9, $325 \pm 6$ ka; Pereira et al., 2017). These assemblages on small flint nodules in the Latium suggest no clear changes of the technology between MIS 11 and MIS 9 in this region.

The heavy-duty tools are the main component of the collected lithic series. Three types of heavy-duty tools are common to the series but in different ratios:

(1) Elongated tools, named bifaces, characterised by a whole bifacial shaping and thin tips. When the cross-section is symmetric, the single series of removals is never rectified by final retouches. Edges are sinuous. When the cross-section is asymmetrical, removals are more numerous and there is a final retouch sometimes rectifying the edges.

(2) Partial tools, named bifacial tools, made by series of removals on the upper part of the tool and the tip. The cross-sections are mainly asymmetric with a preserved back.

(3) Heavy «scrapers », « rabots » on pebbles and pebble-tools.

It is worth mentioning that the shaping mode is not linked to the raw material nature. The few bifaces made on flint, despite intensively shaped, share the same technological features. The partial bifacial tools are mainly made on flakes (easily identified) and on half or entire flat pebbles. These tools are sometimes more bifacial rectilinear scrapers added to a bifacial tip allowing a resharpening of the tool without modifying the general form. It is not the case for the bifaces, where the general bifacial volume suggests tools where size, weight, and the pointed tip are more fundamental than the peripheral edges, which stay sinuous.

The three categories are not stages into a shaping process, but clear distinct types of tools made on supports of various sizes. Most of them are asymmetric tools in cross-section. The whole-worked bifaces are elongated and symmetric in form while the partial bifacial tools are frequently short and asymmetric in form.

Mode of shaping at the studied localities indicates again that

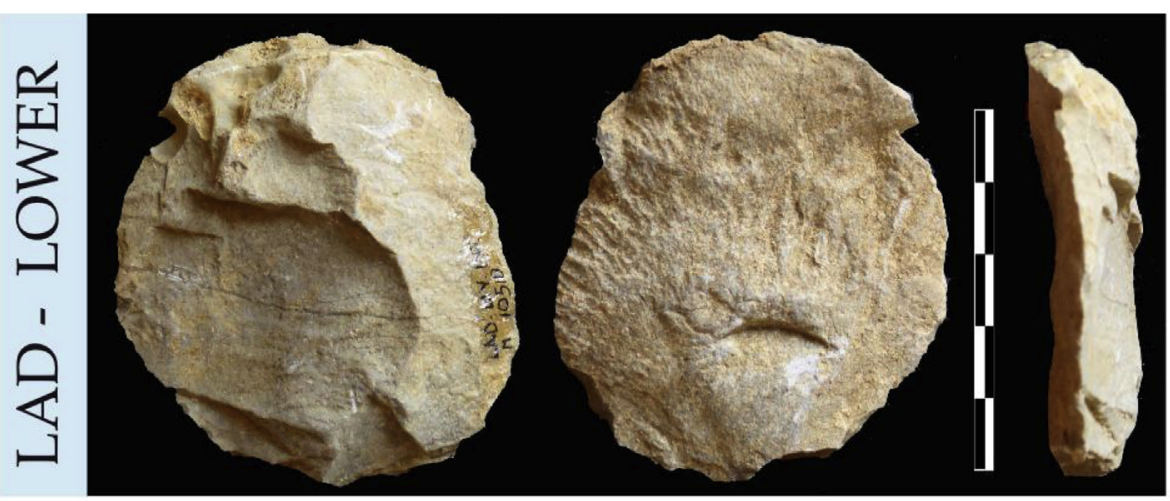

Fig. 9. "Levallois-type" flake from the lower archaeological level of Lademagne. 


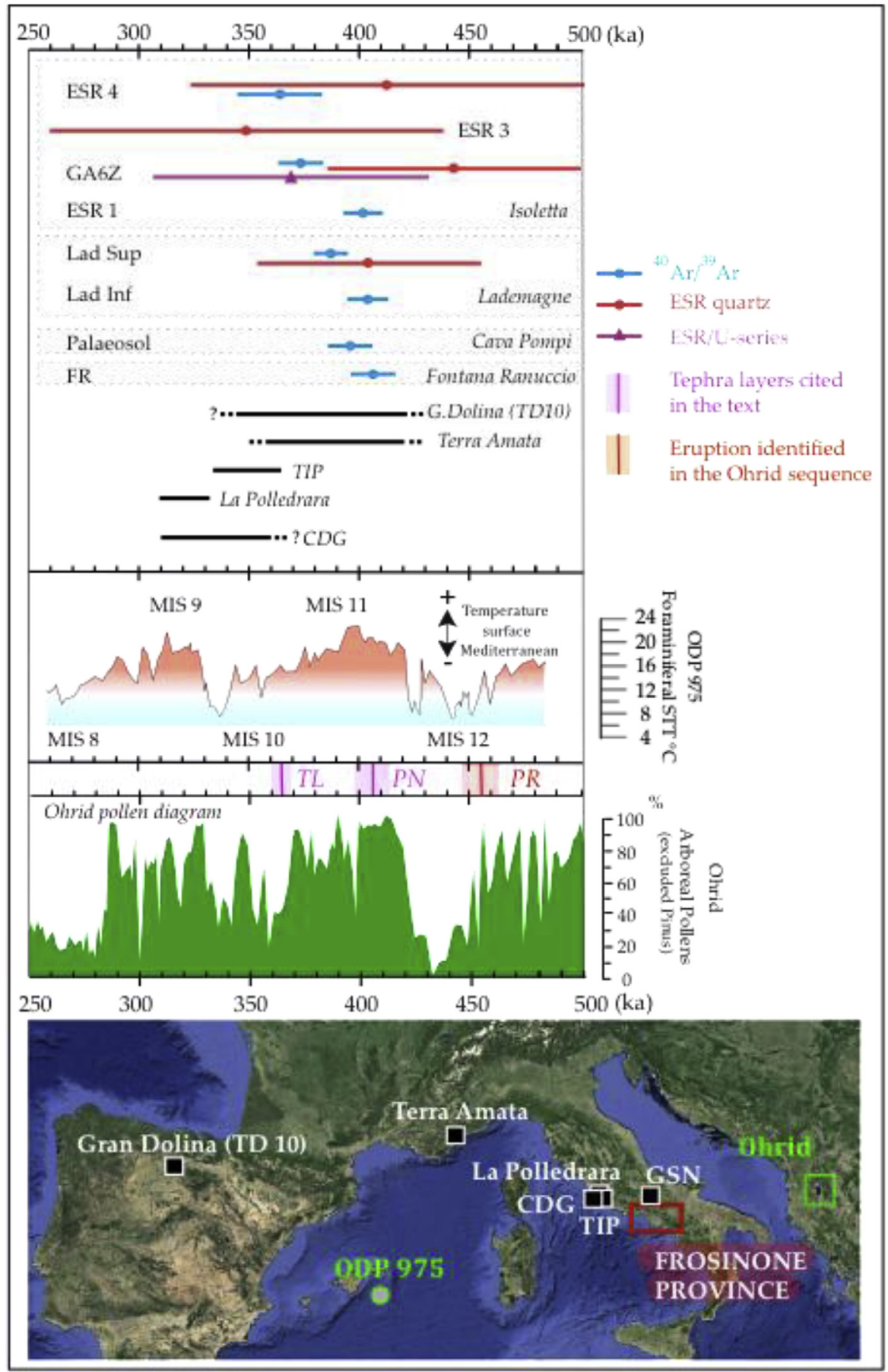

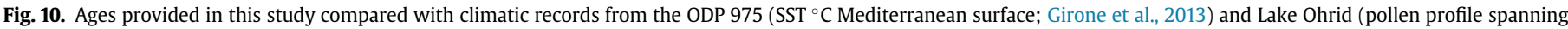

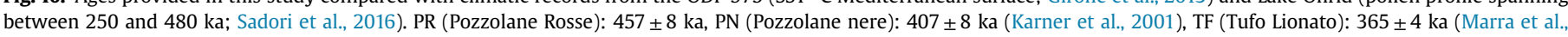

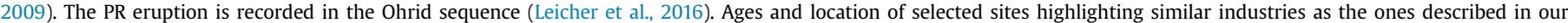
study are correlated. CDG: Castel di Guido; TIP: Torre in Pietra; GSN: Guado San Nicola.

common and distinct features existed during the MIS 11-9 period in Italy in terms of shaping processes and morphological results. For instance, at Torre in Pietra layer "m", bifaces are similar to the ones we investigated in this study, demonstrating an asymmetric crosssection. Equally, at Guado San Nicola (Peretto et al., 2016) bifaces, representing a total $3-4 \%$ of the series, are made mainly in flint and rarely silicified limestone, on slabs and some flakes. The raw material does not influence the shaping mode leading to asymmetric pieces. We furthermore observe a careful shaping of the tips, including final retouches and a limited technical investment. Finally, at Castel di Guido (Boschian and Saccà, 2015), bifacial tools on elephant bones and on pebbles (various stones) indicate first common shaping strategies on this site, whatever the raw materials. For instance, the partial bifacial tools characterised by a main management of the bifacial tip, with addition of a lateral bifacial scraper.

Our lithic series attest that regional trends existed in the Frosinone region during MIS 11 to MIS 11/10 transition, with bifaces, 
bifacial tools and cores managed in the same way. Bifacial tools and bifaces are in general longer than in other Italian sites although sharing common technological strategies. It could be linked to the available raw materials size itself or maybe to the nature of activities for which these tools were predestined. Detailed palaeontological analyses should provide more information about the types of habitat and activities requiring flaking and bifacial technologies. They could help us in future studies to explain the quantitative and qualitative differences observed between the series even if they could also be due to taphonomical processes.

Finally, the Latium presents the particularity to document several well dated sites spanning the MIS 11-9 period, highlighting bones retouched industries, made of elephant fragments of bones such as at Fontana Ranuccio, Isoletta, Lademagne, Cava Pompi, Torre in Pietra, Rignano Flaminio (Segre Naldini et al., 2009; Biddittu et al., 1979, 2012; Biddittu and Segre, 1982; Villa et al., 2016; Petronio et al., 2017), Castel di Guido and La Polledrara di Cecanibbio (Saccà, 2012; Anzidei et al., 2012; Pereira et al., 2017). The Latium is not an isolated case in the Western European area. Some sites of the Mediterranean region from the same time period (i.e. MIS 11-10), for examples Terra Amata (de Lumley et al., 1976) or Gran Dolina TD 10 (MIS 10, Atapuerca; Rosell et al., 2015; Falguères et al., 2013) yielded similar industries suggesting a widespread diffusion of such behaviours in a short period of time starting during MIS 11. The inter-comparison of these industries will be now possible thanks to the better chronological framework obtained for the Frosinone Province and the Latium in general.

\section{Conclusion}

The multimethod geochronological approach applied in this study, including the use of radio-isotopic $\left({ }^{40} \mathrm{Ar} /{ }^{39} \mathrm{Ar}\right.$ on single crystal) and palaeodosimetric (ESR on quartz and ESR/U-series on teeth) dating methods, as well as tephra geochemical fingerprinting, demonstrates that the archaeological sites of Fontana Ranuccio, Lademagne, Isoletta, and Cava Pompi are sub-coeval and cover a relatively short period of time between 408 and $375 \mathrm{ka}$, spanning the MIS 11 climatic optimum to the transition toward the full glacial period MIS 10. Comparison with Mediterranean palaeoclimatic records suggests that the human occupation of the Frosinone province was likely promoted by the particular favourable climatic conditions of the MIS 11, which led in this area to the establishment of a rich terrestrial ecosystem with a great abundance of large mammals, including human, as testified by the richness of archaeological and palaeontological sites of this period.

Hints from the preliminary technological study of small corpus of pieces from Isoletta and Lademagne, but also of the neighbour site of Campogrande, compared with data available in the literature for sites of the Latium, clearly show common strategies during the period comprised between MIS 11 and MIS 9 (410-325 ka) including retouched industries made of elephant bones. It also highlights the specificity of some technological features found only in the Frosinone Province, like bifacial tools relatively big in size, compared to other regions, suggesting particular regional behaviours in Central Italy in this period. Furthermore, the presence of Levallois evidenced in the oldest layer of Lademagne (older than $405 \pm 9 \mathrm{ka}$ ) indicates perhaps a punctual practice of this technology as suggested in the neighbour site of Guado San Nicola (Molise) as early as MIS 11 in Central Italy. The emergence of such a technological innovation during MIS 11 in this region of Italy (e.g. bones industries, Levallois-like technologies) may, at least to some extent, be seen as a cultural adaptation to the relatively long and stable interglacial-like environmental-climatic conditions, which likely offered unprecedented opportunities for the subsistence and development of the hominid populations.

\section{Acknowledgments}

A. Pereira PhD project is granted by the «Ecole Francaise de Rome ». We would also thank the ATM "Les dynamiques socioecosystèmiques, entre perturbations et résiliences environnementales et culturelles" of the Museum national d'Histoire naturelle of Paris (project "Acheulean and volcanism in Italy" conducted by M.H. Moncel (MNHN) and J.J. Bahain (MNHN)) and also the PHC Galileo project no. 28237WA "l'Acheuléen en Italie méridionale: Chronologie, Paleoanthropologie, Cultures' led by J.J. Bahain (MNHN). We specially thank Luciano Bruni, discoverer of the site of Fontana Ranuccio and invaluable protagonist of the excavations. A. Pereira and S. Nomade also express gratitude to Prof. Marcello Piperno for his help in developping the initial projet around the dating of the central italian Middle Pleistocene archaeological sites and for the countless discussions over the last 5 years. This is LSCE contribution $n^{\circ} 6411$.

\section{Appendix A. Supplementary data}

Supplementary data related to this article can be found at https://doi.org/10.1016/j.quascirev.2018.03.021.

\section{References}

Adamiec, G., Aitken, M.J., 1998. Dose-rate conversion factors: update. Ancient TL 16, 37-50.

Adler, D.S., Wilkinson, K.N., Blockley, S., Mark, D.F., Pinhasi, R., Schmidt-Magee, B.A., Nahapetyan, S., Mallol, C., Berna, F., Glauberman, P.J., Raczynski-Henk, Y., Wales, N., Frahm, E., Jöris, O., MacLeod, A., Smith, V.C., Cullen, V.L., Gasparian, B., 2014. Early Levallois technology and the lower to middle paleolithic transition in the southern caucasus. Science 345, 1609-1613.

Akilesh, K., Pappu, S., Rajapara, H.M., Gunnell, Y., Shukla, A.D., Singhvi, A.K., 2018. Early Middle Palaeolithic culture in India around 385-172 ka reframes Out of Africa models. Nature. https://doi.org/10.1038/nature25444.

Anzidei, A.P., Bulgarelli, G.M., Catalano, P. Cerilli, E. Gallotti, R., Lemorini, C., Milli, S., Palombo, M.R., Pantano, W., Santucci, E., 2012. Ongoing research at the late Middle Pleistocene site of La Polledrara di Cecanibbio (central Italy), with emphasis on human elephant relationships. Quat. Int. 255, 171-187.

Ascenzi, A., Biddittu, I., Cassoli, P.F., Segre, A.G., Segre Naldini, E., 1993. Dal Paleolitico inferiore al Bronzo nel bacino di Anagni. In: Gatti, S. (Ed.), Dives Anagnia dalla preistoria alla protostoria. Archeologia della Valle dei Sacco. L'Erma di Bretschneider, Roma, pp. 25-50.

Ascenzi, A., Biddittu, I., Cassoli, P.F., Segre, A.G., Segre Naldini, E., 1996. A calvarium of late Homo erectus from Ceprano, Italy. J. Hum. Evol. 31, 409-423.

Ascenzi, A., Mallegni, F., Manzi, G., Segre, A.G., Segre Naldini, E., 2000. A re-appraisal of Ceprano calvaria affinities with Homo erectus, after the new reconstruction. J. Hum. Evol. 39, 443-450.

Bahain, J.J., Yokoyama, Y., Falguères, C., Sarcia, M.N., 1992. ESR dating of tooth enamel: a comparison with K-Ar dating. Quat. Sci. Rev. 11, 245-250.

Bahain, J.J., Falguères, C., Laurent, M., Voinchet, P., Dolo, J.M., Antoine, P., Tuffreau, A., 2007. ESR chronology of the Somme River Terrace system and first human settlements in Northern France. Quat. Geochronol. 2, 356-362. https://doi.org/ 10.1016/j.quageo.2006.04.012.

Bahain, J.J., Falguères, C., Dolo, J.M., Antoine, P., Auguste, P., Limondin-Lozouet, N., Locht, J.L., Tuffreau, A., 2010. ESR/U-series dating of teeth recovered from wellstratigraphically age-controlled sequences from Northern France. Quat. Geochronol. 5, 371-375.

Basilone, P., Civetta, L., 1975. Datazione K-Ar dell'attività vulcanica dei Mt. Ernici (Latina). Società Italiana Mineralogia e Petrologia 31 (1), 175-179.

Berger, A., Melice, J.L., Loutre, M.F., 2005. On the origin of the 100-ky cycles in the astronomical forcing. Paleoceanography 20, PA4019. https://doi.org/10.1029/ 2005PA001173.

Biddittu, I., 1974. Giacimento pleistocenico ad amigdale acheuleane nel territorio di Ceprano, Frosinone. Memoria dell'Istituto Italiano di Paleontologia Umana 2, $61-67$.

Biddittu, I., 2004. Guida del Museo Preistorico di Pofi. I Quad. di ARGIL 1, 157, 49-58 et, pp. 114-119.

Biddittu, I., Segre, A.G., 1977. Giacimenti preistorici e quaternario della provincial di Frosinone. Boll. Ist. St. e. Arte del Lazio merionale 9 (1-2), 21-44.

Biddittu, I., Segre, A.G., 1978. Paleolitico inferiore a Cava Pompi presso Pofi, Frosinone. Quad. Arch. Etrusco-Italica 1, 78-79.

Biddittu, I., Segre, A.G., 1982. Utilizzazione dell'osso nel Paleolitico inferiore italiano. Estratto dagli atti della XXIII riunione scientifica dell'istituto italiano di preisoria e protostoria Firenze, 7-9 Maggio 1980 89-103.

Biddittu, I., Segre, A.G., 1984. Industria su scheggia e bifacciali: nuovi reperti del paleolitico inferiore ad Anagni-Fontana Ranuccio, Frosinone. In: Atti della XXIV 
riunione scientifica dell'Istituto Italiano di Preistoria e Protostoria, vol. 24, pp. 105-112.

Biddittu, I., Cassoli, P.F., Radicati Di Brozxolo, F., Segre, A.G., Segre Naldini, E., Villa, I., 1979. Anagni a K-Ar dated lower and middle-Pleistocene site, central Italy: preliminary report. Quaternaria 21, 53-71.

Biddittu, I., Piperno, M., Segre, A.G., 1984. Rosaneto Calabria. I primi abitanti d'Europa 1500 000-100 000 anni. In: Mostra realizzata con la collaborazione della regione Lazio assessorato alla cultura. Museo Nazionale Preistorico Etnografico "Luigi Pigorini” Piazzale Marconi n. 14 Roma Eur 151-154.

Biddittu, I., Canetri, E., Comerci, V., Germani, M., Picchi, G., 2012. Nuove ricerche nel giacimento del Paleolitico inferiore di Lademagne, S. Giovanni Incarico (Frosinone). In: Ghini, G., Mari, Z. (Eds.), Lazio e Sabina. Edizioni Quasar, vol. 9, pp. 437-443.

Boari, E., Tommasini, S., Laurenzi, M.A., Conticelli, S., 2009. Transition from ultrapotassic kamafugitic to sub-alkaline magmas: $\mathrm{Sr}, \mathrm{Nd}$, and $\mathrm{Pb}$ isotope, trace element and 40Ar-39Ar age data from the middle Latin valley volcanic field, roman magmatic province, Central Italy. J. Petrol. 50 (7), 1327-1357.

Boschian, G., Saccà, D., 2015. In the elephant, everything is good: carcass use and reuse at Castel di Guido (Italy). Quat. Int. 361, 288-296. https://doi.org/10.1016/ j.quaint.2014.04.030

Brennan, B.J., 2003. Beta doses to spherical grains. Radiat. Meas. 37, 299-303. https://doi.org/10.1016/S1350-4487(03)00011-8.

Brennan, B., Lyons, R., Phillips, S., 1991. Attenuation of alpha particle track dose for spherical grains. Nuclear Tracks Radiational Measurements 18 (1-2), 249-253. https://doi.org/10.1016/1359-0189(91)90119-3.

Brennan, B.J., Rink, W.J., McGuirl, E.L., Schwarcz, H.P., Prestwich, W.V., 1997. Beta doses in tooth enamel by "One Group" theory and the Rosy ESR dating software. Radiat. Meas. 27, 307-314.

Capotondi, L., Girone, A., Lirer, F., Bergami, C., Verducci, M., Vallefuoco, M., Afferri, A., Ferraro, L., Pelosi, N., De Lange, G.J., 2016. Central Mediterranean MidPleistocene paleoclimatic variability and its association with global climate. Palaeogeogr. Palaeoclimatol. Palaeoecol. 442, 72-83.

Carrara, C., Frezzotti, M., Giraudi, C., 1995. Stratigrafia plio-quaternaria. In: Carrara, C. (Ed.), Lazio Meridionale, Sintesi Delle Ricerche Geologiche Multidisciplinari. ENEA, pp. 62-85.

Civetta, L., Innocenti, F., Lirer, L., Manetti, P., Munno, R., Peccirillo, A., Poli, G., Serri, G., 1979. Serie potassica ed alta in potassio dei Monti Ernici (Lazio Meridionale): considerazioni petrologiche e geochimiche. Rend. Soc. Ital. Mineral. Petrol. 35, 227-249.

Civetta, L., Innocenti, F., Manetti, P., Peccerillo, A., Poli, G., 1981. Geochemical characteristics of potassic volcanics from Mt. Ernici (Southern, Latium, Italy). Contrib. Mineral. Petrol. 78, 37-47.

Comerci, V., Biddittu, I., Di Manna, P., Germani, M., Piccardi, L., Ventura, G., Vittori, E., 2015. Tectonic evidence in the palaeolithic site of Lademagne (san Giovanni Incarico - FR, southern Latium, Italy). In: 6th International INQUA Meeting on Paleoseismology, Active Tectonics and Archaeoseismology 19-24 April 2015. INQUA Focus Group on Paleoseismology and Active Tectonics, Pescina, Fucino Basin, Italy.

Conard, N.J., Serangeli, J., Utz, B., Urban, B., Kolfschoten, T. Van, Miller, C.E., Starkovich, B.M., 2015. Excavations at Schöningen and paradigm shifts in human evolution. J. Hum. Evol. 89, 1-17. https://doi.org/10.1016/ j.jhevol.2015.10.003.

de Lumley, H., de Lumley, M.A., Miskovsky, J.C., Renault-Miskovsky, J., 1976. Le site de Terra Amata. In: de Lumley, H., Barral, L. (Eds.), Sites paléolithiques de la région de Nice et grottes de Grimaldi, IX Congres UISPP, Livret-guide Excursion B1, Nice, 15-49.

Degeai, J.P., Villa, V., Chaussé, C., Pereira, A., Nomade, S., Aureli, D., Pagli, M., Nicoud, E., 2018. Chemical weathering of palaeosols from the lower palaeolithic site of valle Giumentina, central Italy. Quat. Sci. Rev. 183, 88-109.

Deino, A., Potts, R., 1990. Single-crystal ${ }^{40} \mathrm{Ar} /{ }^{39} \mathrm{Ar}$ dating of the olorgesailie formation, Southern Kenya Rift. J. Geophys. Res. 95, 8453-8470.

Di Vincenzo, F., Profico, A., Bernardini, F., Cerroni, V., Dreossi, D., Schlager, S., Zaio, P. Benazzi, S., Biddittu, I., Rubini, M., Tuniz, C., Manzi, G., 2017. Digital reconstruction of the Ceprano calvarium (Italy) and implications for its interpretation. Sci. Rep. 7 (13974), 1-11.

Duval, M., Grün, R., 2016. Are published ESR dose assessments on fossil tooth enamel reliable? Quat. Geochronol. 31, 19-27.

Duval, M., Guilarte, V., 2015. ESR dosimetry of optically bleached quartz grains extracted from Plio-quaternary sediment: evaluating some key aspects of the ESR signal associated to the Ti-center. Radiat. Meas. 78, 28-41.

Duval, M., Grün, R., Falguères, C., Bahain, J.J., Dolo, J.M., 2009. ESR dating of Lower Pleistocene fossil teeth: limits of the single saturating exponential (SSE) function for the equivalent dose determination. Radiat. Meas. 44, 477-48.

Falguères, C., Bahain, J.J., Bischoff, J.L., Pérez-Gonzàlez, A., Ortega, A.I., Ollé, A., Quiles, A., Ghaleb, B., Moreno, D., Dolo, J.M., Shao, Q., Vallverdù, J., Carbonell, E., Bermùdez de Castro, J.M., Arsuaga, J.L., 2013. Combined esr/u-series chronology of acheulian hominid-bearing layers at trinchera galeria site, atapuerca, spain. J. Hum. Evol. 65, 168-184. https://doi.org/10.1016/j.jhevol.2013.05.005.

Freda, C., Gaeta, M., Palladino, D.M., Trigila, R., 1997. The Villa Senni eruption Alban Hills, central Italy): the role of $\mathrm{H}_{2} \mathrm{O}$ and $\mathrm{CO}_{2}$ on the magma chamber evolution and on the eruptive scenario. J. Volcanol. Geotherm. Res. 78, 103-120.

Gaeta, M., Freda, C., Marra, F., Arienzo, I., Gozzi, F., Jicha, B., Di Rocco, T., 2016. Paleozoic metasomatism at the origin of Mediterranean ultrapotassic magmas: constraints from time-dependent geochemistry of Colli Albani volcanic products (Central Italy). Lithos 244, 151-164.
Giaccio, B., Arienzo, I., Sottili, G., Castorina, F., Gaeta, M., Nomade, S., Galli, P. Messina, P., 2013. Isotopic (Sr-Nd) and major element fingerprinting of distal tephras: an application to the Middle-Late Pleistocene markers from the Colli Albani volcano, central Italy. Quat. Sci. Rev. 67, 190-206. https://doi.org/ 10.1016/j.quascirev.2013.01.028.

Giaccio, B., Regattieri, E., Zanchetta, G., Nomade, S., Renne, P.R., Sprain, C.J. Drysdale, R.N., Tzedakis, P.C., Messina, P., Scardia, G., Sposato, A., Bassinot, F., 2015. Duration and dynamics of the best orbital analogue to the present interglacial. Geology 43, 603-606.

Giannetti, B., 2001. Origin of the calderas and evolution of the Roccamonfina volcano (Roman region, Italy). J. Volcanol. Geoth. Res. 106, 301-319.

Girone, A., Maiorano, P., Marino, M., Kucera, M., 2013. Calcareous plankton response to orbital and millennial-scale climate changes across the Middle Pleistocene in the western Mediterranean. Palaeogeogr. Palaeoclimatol. Palaeoecol. 392, 105-116.

Gliozzi, E., Abbazi, L., Ambrosetti, P., Argenti, P., Azzaroli, A., Caloi, L., Capasso Barbato, L., Di Stefano, G., Esu, D., Ficcarelli, G., Girotti, O., Kotsakis, T., Masini, F., Mazza, P., Mezzabotta, C., Palombo, M.R., Petronio, C., Rook, L., Sala, B., Sardella, R., Zanalda, E., Torre, D., 1997. Biochronology of selected mammals, molluscs and ostracods from the middle Pliocene to the late pleistocene in Italy. The state of the art. Riv. Ital. Paleontol. Stratigr. 103, 369-388.

Grün, R., 1994. A cautionary note: use of the "water content" and "depth for cosmic ray dose rate" in AGE and DATA. Ancient TL 12, 50-51.

Grün, R., Katzenberger-Apel, O., 1994. An alpha irradiator for ESR dating. Ancient TL $12,35-38$.

Grün, R., Schwarcz, H.P., Chadam, J.M., 1988. ESR dating of tooth enamel: coupled correction for U-uptake and U-series disequilibrium. Nucl. Tracks Radiat. Meas. $14,237-241$.

Head, M.J., Gibbard, P.L., 2015. Early-Middle Pleistocene transitions: linking terrestrial and marine realms. Quat. Int. 389, 7-46. https://doi.org/10.1016/ j.quaint.2015.09.042.

Head, M.J., Pillans, B., Farquhar, S., 2008. The Early Middle Pleistocene Transition: characterization and proposed guide for the defining boundary. Episodes 31 255-259.

Hofreiter, M., Stewart, J., 2009. Ecological change, range fluctuations and population dynamics during the pleistocene. Curr. Biol. 19, R584-R594. https://doi.org/ 10.1016/j.cub.2009.06.030.

Karner, D.B., Marra, F., 1998. Correlation of fluviodeltaic aggradational sections with glacial climate history; A revision of the Pleistocene stratigraphy of Rome. Geol. Soc. Am. Bull. 110, 748-758.

Karner, D.B., Marra, F., Renne, P.R., 2001. The history of the Monti Sabatini and Alban Hills volcanoes: groundwork for assessing volcanic-tectonic hazards for Rome. J. Volcanol. Geoth. Res. 107, 185-219.

Kretzoi, M., Dobosi, V.T. (Eds.), 1990. Vértesszőlős, Site, Man and Culture. Akadémiai Kiado, Budapest.

Laurent, M., Falguères, C., Bahain, J.J., Rousseau, L., Van Vliet-Lanoë, B., 1998. ESR dating of quartz extracted from Quaternary and Neogene sediments: method, potential and actual limits. Quat. Sci. Rev. 17, 1057-1061.

Lee, J.Y., Marti, K., Severinghaus, J.P., Kawamura, K., Hee-Soo, Y., Lee, J.B., Kim, J.S. 2006. A redetermination of the isotopic abundances of atmospheric Ar. Geochimica Cosmochima Acta 70, 4507-4512.

Leicher, N., Zanchetta, G., Sulpizio, R., Giaccio, B., Wagner, B., Nomade, S., Francke, A. Del Carlo, P., 2016. First tephrostratigraphic results of the DEEP site record from Lake Ohrid (Macedonia and Albania). Biogeosciences 13, 2151-2178.

Locardi, E., 1988. The origin of Apenninic arcs. Tectonophysics 146, 105-123.

Ludwig, K.R., 2001. Isoplot 3.0a Geochronological Toolkit for Microsoft Excel. Special Publication No. 4. Berkeley Geochronology Center, Berkeley, CA.

Manzi, G., 2016. Humans of the Middle Pleistocene: the controversial calvarium from Ceprano (Italy) and its significance for the origin and variability of Homo heidelbergensis. Quat. Int. 411, 254-261.

Manzi, G., Mallegni, F., Ascenzi, A., 2001. A cranium for the earliest Europeans: phylogenetic position of the hominid from Ceprano, Italy. Proceedings of the National Academy of Sciences USA 98, 10011-10016.

Manzi, G., Magri, D., Milli, S., Palombo, M.R., Margari, V., Celiberti, V., Barbieri, M., Barbieri, Mz, Melis, R.T., Rubini, M., Ruffo, M., Saracino, B., Tzedakis, P.C., Zarattini, A., Biddittu, I., 2010. The new chronology of the Ceprano calvarium (Italy). J. Hum. Evol. 59, 580-585.

Marra, F., Karner, D.B., Freda, C., Gaeta, M., Renne, P.R., 2009. Large mafic eruptions at the Alban Hills Volcanic District (Central Italy): chronostratigraphy, petrography and eruptive behavior. J. Volcanol. Geoth. Res. 179, 217-232.

Marra, F., Sottili, G., Gaeta, M., Giaccio, B., Jicha, B., Masotta, M., Palladino, D.M., Deocampo, D.M., 2014. Major explosive activity in the Monti Sabatini Volcanic District (central Italy) over the 800-390ka interval: geochronologicalgeochemical overview and tephrostratigraphic implications. Quat. Sci. Rev. 94, 74-101. https://doi.org/10.1016/j.quascirev.2014.04.010.

Marra, F., Florindo, F., Anzidei, M., Sepe, V., 2016. Paleo-surfaces of glacioeustatically forced aggradational successions in the coastal area of Rome: assessing interplay between tectonics and sea-level during the last ten interglacials. Quat. Sci. Rev. 148, 85-100. https://doi.org/10.1016/ j.quascirev.2016.07.003.

Mercier, N., Falguères, C., 2007. Field gamma dose-rate measurement with a NaI (Tl) detector: re-evaluation of the "threshold" technique. Ancien TL 25, 1-4.

Moncel, M.H., Despriée, J., Voinchet, P., Tissoux, H., Moreno, D., Bahain, J.J., Courcimault, G., Falguères, C., 2013. Early evidence of acheulean settlement in northwestern Europe - La noira site, a 700000 year-old occupation in the 
center of France. PLoS One 8. https://doi.org/10.1371/journal.pone.0075529.

Moncel, M.H., Arzarello, M., Peretto, C., 2016. The hoslteinian period in Europe (MIS 11-19). Quat. Int. 409 https://doi.org/10.1016/j.quaint.2016.06.006.

Moncel, M.H., Landais, A., Lebreton, V., Combourieu-Nebout, N., Nomade, S., Bazin, L., 2017. Linking environmental changes with human occupations between 900 and $400 \mathrm{ka}$ in Western Europe. Quat. Int. (in press) https://doi.org/ 10.1016/j.quaint.2016.09.065

Murray, A.S., Roberts, R.G., 1997. Determining the burial time of single grains of quartz using optically stimulated luminescence. Earth Planet Sci. Lett. 152 $163-180$.

Muttoni, G., Scardia, G., Kent, D.V., Swisher, C.C., Manzi, G., 2009. Pleistocene magnetochronology of early hominin sites at Ceprano and Fontana Ranuccio, Italy, Earth Planet Sci. Lett. 286, 255-268.

Naldini, E.S., Muttoni, G., Parenti, F., Scardia, G., Segre, A.G., 2009. Nouvelles recherches dans le bassin Plio-Pléistocène d'Anagni (Latium méridional, Italie). L'Anthropologie 113, 66-77. https://doi.org/10.1016/j.anthro.2009.01.013.

Nicoud, E., Aureli, D., Pagli, M., Villa, V., Chaussé, C., Agostini, S., Bahain, J.J., Boschian, G., Degeai, J.P., Fusco, F., Giaccio, B., Hernandez, M., Kuzucuoglu, C., Lahaye, C., Lemorini, C., Limondin-Lozouet, N., Mazza, P., Mercier, N. Nomade, S., Pereira, A., Robert, V., Rossi, M.A., Virmoux, C., Zupancich, A., 2016 Preliminary data from valle Giumentina pleistocene site (abruzzo, Central Italy): a new approach to a clactonian and acheulian sequence. Quat. Int. 409, 182-194. https://doi.org/10.1016/j.quaint.2015.08.080.

Niespolo, E.M., Rutte, D., Deino, A., Renne, P.R., 2016. Intercalibration and age of the Alder Creek sanidine ${ }^{40} \mathrm{Ar} /{ }^{39} \mathrm{Ar}$ standard. Quat. Geochronol. 39, 205-213. https://doi.org/10.1016/j.quageo.2016.09.004.

Nomade, S., Renne, P.R., Vogel, N., Deino, A.L., Sharp, W.D., Becker, T.A., Jaouni, A.R. Mundil, R., 2005. Alder Creek sanidine (ACs-2), A Quaternary ${ }^{40} \mathrm{Ar} /{ }^{39} \mathrm{Ar}$ dating standard tied to the Cobb Mountain geomagnetic event. Chem. Geol. 218 315-338.

Nomade, S., Gauthier, A., Guillou, H., Pastre, J.F., 2010. ${ }^{40} \mathrm{Ar} /{ }^{39} \mathrm{Ar}$ temporal framework for the Alleret maar lacustrine sequence (French Massif Central): volcanological and Paleoclimatic implications. Quat. Geochronol. 5, 20-27.

Nomade, S., Muttoni, G., Guillou, H., Robin, E., Scardia, G., 2011. First ${ }^{40} \mathrm{Ar} /{ }^{39} \mathrm{Ar}$ age of the Ceprano man (central Italy). Quat. Geochronol. 6, 453-457.

Oliveira, D., Desprat, S., Rodrigues, T., Naughton, F., Hodell, D., Trigo, R., Rufino, M. Lopes, C., Abrantes, F., Sánchez Goñi, M.F., 2016. The complexity of millennialscale variability in southwestern Europe during MIS 11. Quat. Res. 1-15. https://doi.org/10.1016/j.yqres.2016.09.

Orain, R., Lebreton, V., Russo Ermolli, E., Sémah, A.M., Nomade, S., Shao, Q. Bahain, J.J., Thun Hohenstein, U., Peretto, C., 2013. Hominin responses to environmental changes during the Middle Pleistocene in central and southern Italy. Clim. Past 9, 687-697. https://doi.org/10.5194/cp-9-687-2013.

Pereira, A., Nomade, S., Voinchet, P., Bahain, J.J., Falguères, C., Garon, H., Lefèvre, D. Raynal, J.P., Scao, V., Piperno, M., 2015. The earliest securely dated hominin fossil in Italy and evidence of Acheulian occupation during glacial MIS 16 at Notarchirico (Venosa, Basilicata, Italy). J. Quat. Sci. 30, 639-650. https://doi.org/ 10.1002 /jqs. 2809.

Pereira, A., Nomade, S., Shao, Q., Bahain, J.J., Arzarello, M., Douville, E., Falguères, C. Frank, N., Garcia, T., Lembo, G., Muttillo, B., Scao, V., Peretto, C., 2016. ${ }^{40} \mathrm{Ar} /{ }^{39} \mathrm{Ar}$ and ESR/U-series dates for Guado san Nicola, middle pleistocene key site at the lower/middle palaeolithic transition in Italy. Quat. Geochronol. 36, 67-75.

Pereira, A., Nomade, S., Falguères, C., Bahain, J.J., Tombret, O., Garcia, T., Voinchet, P. Bulgarelli, G.M., Anzidei, A.P., 2017. New ${ }^{40} \mathrm{Ar} /{ }^{39} \mathrm{Ar}$ and ESR/U-series data for La Polledrara di Cecanibbio archaeological site (Lazio, Italy). J. Archaeol. Sci. Report 15, 20-29.

Peretto, C., Arzarello, M., Bahain, J.J., Boulbes, N., Dolo, J.M., Douville, E., Falguères, C., Frank, N., Garcia, T., Lembo, G., Moigne, A.M., Muttillo, B., Nomade, S., Pereira, A., Rufo, M.A., Sala, B., Shao, Q., Thun Hohenstein, U., Tessari, U., Turrini, M.C., Vaccaro, C., 2016. The middle pleistocene site of Guado san Nicola (monteroduni, Central Italy) on the lower/middle palaeolithic transition. Quat. Int. 411, 301-315. https://doi.org/10.1016/j.quaint.2015.11.056.

Petronio, C., Ceruleo, P., Marra, F., Pandolfi, L., Rolfo, M.F., Salari, L., Sottili, G., Moro, P.A., 2017. A novel multidisciplinary bio- and geo-chronological approach for age determination of Palaeolithic bone artifacts in volcanic settings: an example from eastern Sabatini, Latium, Italy. Quat. Int. 1-9. https://doi.org/ 10.1016/j.quaint.2017.02.010.

Petrosino, P., Jicha, B.R., Mazzeo, F.C., Russo Ermolli, E., 2014. A high resolution tephrochronological record of MIS 14-12 in the Southern Apennines (Acerno Basin, Italy). J. Volcanol. Geoth. Res. 274, 34-50. https://doi.org/10.1016/ j.jvolgeores.2014.01.014.

Prescott, J.R., Hutton, J.T., 1994a. Cosmic ray contributions to dose rates for luminescence and ESR dating: large depths and long-term time variations. Radiat. Meas. 23, 497-500.

Prescott, J.R., Hutton, J.T., 1994b. Cosmic ray contributions to dose rates for luminescence and ESR dating: large depths and long-term time variations. Radiat. Meas. 23, 497-500.

Regattieri, E., Giaccio, B., Galli, P., Nomade, S., Peronace, E., Messina, P., Sposato, A. Boschi, C.,, Gemelli, M., 2016. A multi-proxy record of MIS 11-12 deglaciation and glacial MIS 12 instability from the Sulmona basin (central Italy). Quat. Sci. Rev. 132, 129-145. https://doi.org/10.1016/j.quascirev.2015.11.015.

Renne, P.R., Mundil, R., Balco, G., Min, K., Ludwig, K.R., 2011. Joint determination of ${ }^{40} \mathrm{~K}$ decay constants and ${ }^{40} \mathrm{Ar}^{*} /{ }^{40} \mathrm{~K}$ for the Fish Canyon sanidine standard, and improved accuracy for ${ }^{40} \mathrm{Ar} /{ }^{40} \mathrm{Ar}$ geochronology. Response to the comment by W.H. Schwarz et al. on Geochimica Cosmochimica Acta 75, 5097-5100.
Richter, D., Grün, R., Joannes-Boyau, R., Steele, T.E., Amani, F., Rué, M., Fernandes, P., Raynal, J.P., Geraads, D., Ben-Ncer, A., Hublin, JJ., McPherrron, S.P., 2017. The age of the hominin fossils from jebel irhoud, Morocco, and the origins of the middle stone age. Nature 546, 293-296. https://doi.org/10.1038/nature22335.

Rosell, J., Blasco, R., Fernandez Peris, J., Carbonell, E., Barkai, R., Gopher, A., 2015. Recycling bones in the middle pleistocene: some reflections from gran dolina TD10-1 (Spain), bolomor cave (Spain) and qesem cave (Israel). Quat. Int. 361, 297-312. https://doi.org/10.1016/j.quaint.2014.08.009.

Rouchon, V. Gillot, P.Y., Quidelleur, X., Chiesa, S., Floris, B., 2008. Temporal evolution of the Roccamonfina volcanic complex (Pleistocene), Central Italy). J. Volcanol. Geoth. Res. 177, 500-514.

Rubini, M., Cerroni, V., Festa, G., Sardella, R., Zaio, P., 2014. A revision of hominin fossil teeth from Fontana Ranuccio (MiddlePleistocene, Anagni, Frosinone, Italy). J. Hum. Evol. 77, 204-216. https://doi.org/10.1016/j.jhevol.2014.09.002.

Russo Ermolli, E.R., Cheddadi, R., 1997. Climatic reconstruction during the Middle Pleistocene: a pollen record from Vallo di Diano (Southern Italy). Geobios 30, 735-744. https://doi.org/10.1016/S0016-6995(97)80176-3.

Saccà, D., 2012. Taphonomy of Palaeloxodon antiquus at Castel di Guido (Rome, Italy): proboscidean carcass exploitation in the Lower Palaeolithic. Quat. Int. 276-277, 27-41.

Sadori, L., Koutsodendris, A., Panagiotopoulos, K., Masi, A., Bertini, A., CombourieuNebout, N., Francke, A., Kouli, K., Joannin, S., Mercuri, A.M., Peyron, O., Torri, P., Wagner, B., Zanchetta, G., Sinopoli, G., Donders, T.H., 2016. Pollen-based paleoenvironmental and paleoclimatic change at Lake Ohrid (south-eastern Europe) during the past $500 \mathrm{ka}$. Biogeosciences 13, 1423-1437. https://doi.org/10.5194/ bg-13-1423-2016.

Sani, F., Del Ventisette, C., Montanari, D., Coli, M., Nafissi, P., Piazzini, A., 2004. Tectonic evolution of the internal sector of the Central Apennines, Italy. Mar. Petrol. Geol. 21, 1235-1254.

Sardella, R., Palombo, M.R., Petronio, C., Bedetti, C., Pavia, M., 2006. The early Middle Pleistocene large mammal faunas of Italy: an overview. Quat. Int. 149, 104-109.

Scaillet, S., Vita-Scaillet, G., Guillou, H., 2008. Oldest human footprints dated by Ar/ Ar. Earth Planet Sci. Lett. 275, 320-325.

Segre, A.G., Ascenzi, A., 1984. Fontana Ranuccio, Italy's earliest middle pleistocene hominid site. Curr. Anthropol. 25, 230-238.

Segre Naldini, E., Muttoni, G., Parenti, F., Scardia, G., Segre, A.G., 2009. Nouvelles recherches dans le bassin Plio-Pléistocène d'Anagni (Latium méridional, Italie). L'anthropologie 113, 66-77.

Shao, Q., Bahain, J.J., Falguères, C., Peretto, C., Arzarello, M., Minelli, A., Hohenstein, U.T., Dolo, J.-M., Garcia, T., Frank, N., Douville, E., 2011. New ESR/Useries data for the early middle Pleistocene site of Isernia la Pineta, Italy. Radiat. Meas. 46, 847-852.

Shao, Q., Bahain, J.J., Dolo, J.M., Falguères, C., 2014. Monte Carlo approach to calculate US-ESR ages and their uncertainties. Quat. Geochronol. 22, 99-106.

Steiger, R.H., Jäger, E., 1977. Subcommission on geochronology: convention on the use of decay constants in geo- and cosmochronology. Earth Planet Sci. Lett. 6, 359-362.

Toyoda, S., Falguères, C., 2003. The Method to Represent the ESR Signal Intensity of the Aluminium Hole Center in Quartz for the Purpose of Dating, vol. 20. Advances in ESR applications, pp. 7-10.

Tzedakis, P.C., 2007. Seven ambiguities in the Mediterranean palaeoenvironmental narrative. Quat. Sci. Rev. 26, 2042-2066. https://doi.org/10.1016/ j.quascirev.2007.03.014.

Vandenbergue, D., De Corte, F., Buylaert, J.P., Kucera, J., Van den haute, P., 2008. On the internal radioactivity in quartz. Radiat. Meas, 43, 771-775.

Vezzani, L., Festa, A., Ghisetti, F.C., 2010. Geology and tectonic evolution of the central-southern Apennines, Italy. The Geology Society of America 1-58 special paper 469

Vietti, A., 2016. Combined Electron Spin Resonance and U-series Dating (ESR/Useries) of Fossil Tooth Enamel: Application to Dental Remains from Different Palaeolithic Italian Sites. Master thesis in Material Science for Cultural Heritage (LM-53). Università degli Studi di Torino, p. 84. unpublished.

Villa, P., Soriano, S., Grün, R., Marra, F., Nomade, S., Pereira, A., Boschian, G., Pollarolo, L., Fang, F., Bahain, J.J., 2016. The acheulian and early middle paleolithic in Central Italy: stability and innovation. PLoS One 11 (8). https://doi.org/ 10.1371/journal.pone.0160516 e0160516

Voinchet, P., Bahain, J.-J., Falguères, C., Laurent, M., Dolo, J.-M., Despriée, J., Gageonnet, R., 2004. ESR dating of quartz extracted from Quaternary sediments: application to fluvial terraces system of Northern France. Quaternaire 15, 135-141.

Voinchet, P., Despriée, J., Tissoux, H., Falguères, C., Bahain, J.J., Gageonnet, R., Dépont, J., Dolo, J.M., 2010. ESR chronology of alluvial deposits and first human settlements of the Middle Loire Basin (Region Centre, France). Quat. Geochronol. 5, 381-384. https://doi.org/10.1016/j.quageo.2009.03.005.

Voinchet, P., Yin, G., Falguères, C., Liu, C., Fei, H., Sun, X., Bahain, J.J., 2013. ESR dose response of the $\mathrm{Al}$ center measured in quartz samples from the yellow river ( China ): IMPLICATIONS for the dating of upper pleistocene sediment. Geochronometria 40, 341-347. https://doi.org/10.2478/s13386-013-0131-8.

Yokoyama, Y., Nguyen, H.V., 1980. Direct and non destructive dating of marine sediments, manganese nodules and corals by high resolution gamma-ray spectrometry. In: Goldberg, E.D., Horibe, Y., Saruhashi, K. (Eds.), Isotope Marine Chemistry, Uchida Rokakuho, Tokyo, 259-289.

Yokoyama, Y., Falguères, C., Quaegebeur, J.P., 1985. ESR dating of quartz from Quaternary sediments: first attempts. Nucl. Tracks 10, 921-928. 